\title{
THE PITFALLS OF OBVIOUSNESS
}

\section{THE SELF-FRAMING PICTURE AND THE "TELEOLOGY” OF PAINTING IN A LATE SELF-PORTRAIT BY REMBRANDT}

\begin{abstract}
This study aims at a new interpretation of the late Rembrandt's mysterious Self-Portrait with Two Circles at Kenwood House (1665). Former readings of the picture neglected the fact that in this case the work of painting itself became the explicit subject. Both the psychological evocativeness of the personality represented and the "circles" as enigmatic symbols elicited especial interest as they are very much in evidence - and although commentators realized the presence of the brush, palette and mahlstick, practically noone took notice of the work in progress itself, vanishing behind the figure in the grey area of the unusually light background. Following Gary Schwartz I argue that with the two circles Rembrandt refers to the legendary contest of Apelles and Protogenes told by Pliny and Vasari's famous story about Giotto's "O" - both stories are about the competence of the painters to understand abstract tracks as signs of artistic skills. By minimizing the iconic difference between the real and the painted canvas, Rembrandt indicates his ambition to be part of the contest of the great painters of the past - by showing himself present as an imaginary person before the imaginary canvas, and, at the same time, by calling attention to the presence of the material tracks of his "rembrandtian" manner, put between the fine tracks of his ancient predecessors, on the real canvas.
\end{abstract}

Keywords: Rembrandt, self-portrait, figure/ground, iconic difference, painting as a performative

Part of the collection of the Iveagh Bequest at Kenwood House, London, and now commonly dated after 1665, this fascinating self-portrait by the old Rembrandt ${ }^{1}$ is merely the third (and last) one in which he represents himself directly as a painter, with palette, brushes and mahlstick in hand (Fig. 1). In this regard it is only preceded by the 1660 self-portrait at the Louvre (Fig. 2), poignant despite its simplicity ${ }^{2}$ and the famous, socalled Laughing Self-Portrait (1662-63) of Cologne (Fig. 3), in which he appears in a setting that might be a studio, in the role of Zeuxis, the legendary antique painter who laughed himself to death. ${ }^{3}$ Though several of his earlier self-portraits already served the representation of his vocation and social standing, the work of painting became an explicit subject only in the

\footnotetext{
* Prof. András Rényi, Institute of Art History, Faculty of Humanities, Eötvös Loránd University, Budapest; e-mail: renyi.andras@btk.elte.hu
}

work of the old Rembrandt - and it is unclear why. ${ }^{4}$ There is, in any case, a strong temptation to relate this curious iconographic development also to the exceptional painterly complexity of these late, self-reflective works - and I myself wish to succumb to this temptation in this paper, apropos of the Kenwood painting.

Because the temptation is generated by the works themselves. And if we want to respond to them, we cannot but start from the immediate visual characteristics of the paintings, from our elementary experiences as viewers. If, for instance, we step before the painting to be discussed, the one at Kenwood House, there will certainly be one thing we cannot but acknowledge: the extraordinary liveliness of the figure ("Rembrandt"). We cannot but agree with the succinct characterization of one of the most recent monographs on the self-portraits, by H. Perry Chapman: "His frontal, three-quarter-length pose creates an overwhelming, immediate presence. He stands, confronting the viewer, his arms positioned to broaden his already 
massive body. The assertive handling of the face, built up with thick impasto and incised with the butt end of the brush, focuses our attention on his direct gaze." 5 Personal immediacy, the obviousness of presence is the first and most powerful experience of the viewer of
Rembrandt's late portraits: the robust build of a man who has seen much, along with his piercing look, have such magnetism which practically makes all other details - the clothes, the tools, the circles in the background, the mode of painting - appear as secondary

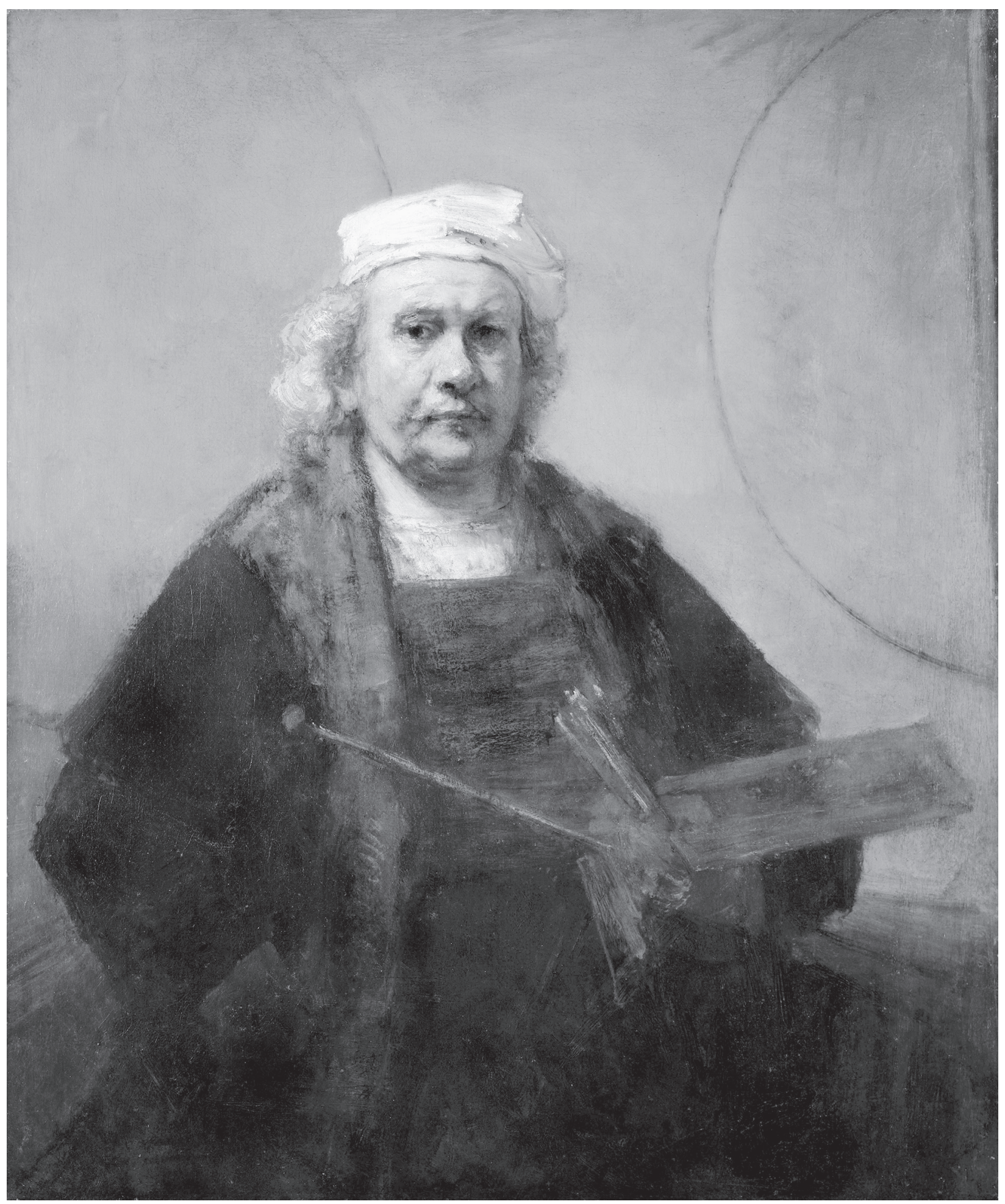

Fig. 1. Rembrandt: Self-Portrait with Two Circles, 1665; oil on canvas, $114.3 \times 94$ cm; London, Kenwood House, Iveagh Bequest 


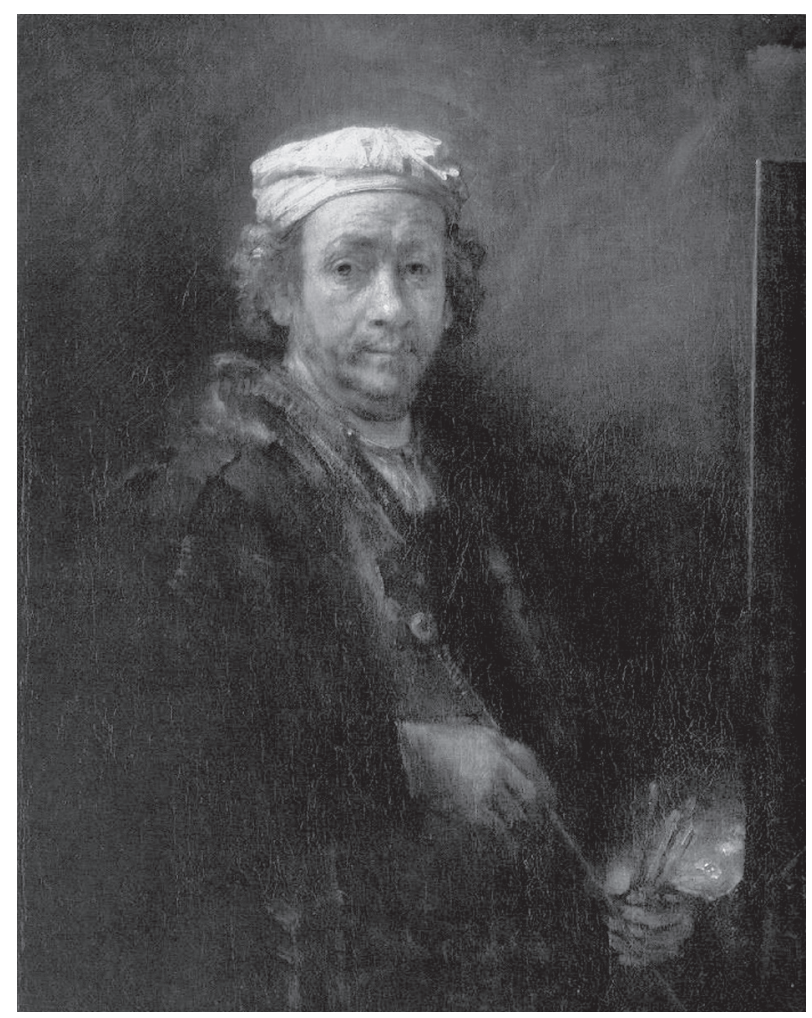

Fig. 2. Rembrandt: Self-Portrait with Easel, 1660; oil on canvas, $110.9 \times 90.6 \mathrm{~cm}$; Paris, Louvre

circumstances, indifferent contingencies. So powerful is this effect that for long decades, the discourse on the late Rembrandt's self-portraits was all but exclusively determined by the persistent notion of a confessional lyrical "I" in the centre. The idea, in other words, that the picture suggests a painter who speaks, if silently. There have been a number of attempts at "hearing," so to speak, what the painting says, to convert the subjective confession into a verbal form, which we are witnesses to while looking at the image.

Naive and absurd as the idea is, it is also inevitable; nor was it alien to Rembrandt's contemporaries already. There is, after all, no portrait that does not occupy a position on an expectation horizon of a "speech situation" shared by the model and the viewer, of their mutual presence; none that does not rely on the shared nature of certain reception attitudes, and

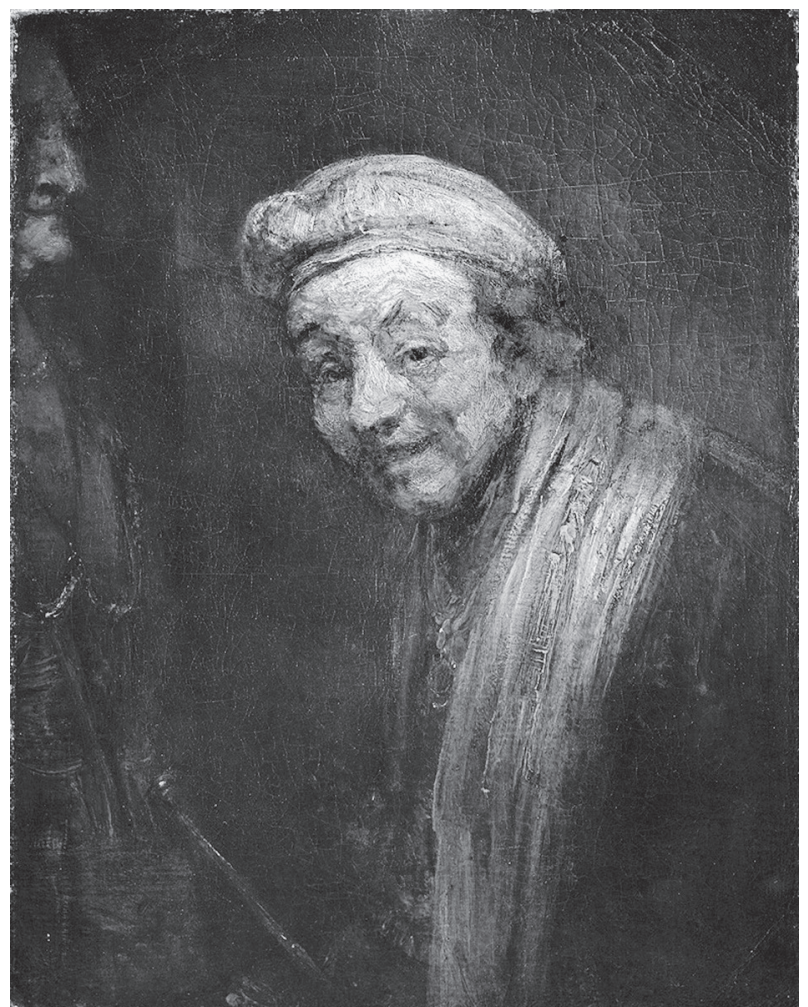

Fig. 3. Rembrandt: Self-Portrait as Zeuxis, 1662-63; oil on canvas, $82.5 \times 65 \mathrm{~cm}$; Köln, Wallraf-Richartz Museum

historically established interpretation routines. We have learnt much about the "rhetoricity" of portraits, the nature and evolution of related expectations and norms in the Dutch Republic of the seventeenth century. Of course, I do not think that an art historian with a modicum of historical competence should take the classic hermeneutical position of the translator; that as a viewer, his or her task is to be better than anyone else at understanding Rembrandt's "message" in, say, the Kenwood picture, and rendering it in precise verbal form. At the same time, I am convinced we cannot dismiss the problem of the communicative nature of the painting simply by saying that art historians have nothing to do with poetic fabrications. The challenge of the speaking painting is as obvious today as at any time before: this is then what we must question first. 


\section{UNDER THE SPELL OF CONFESSIONS}

"Do you remember? back then... That too was you. This too was you. You are both this and that. Is it fair for someone to be such a human-faced, old dog? A piece of rag. Even your hand is trembling. It is not even your hand as it was, I don't recognize it!"6

We do not know which self-portrait of the old Rembrandt prompted the renowned Hungarian author Sándor Bródy to commit to paper the lines quoted in the motto. Nor does it probably matter: after all, the lyrical confession of the old man who mutters before his own self-portrait boils down to the fact of life that "you are both this and that"; to the essential experience that in the painted face the whole of life is somehow preserved and presented to the viewer. The short story in which that remark occurs is the poetic encapsulation of an experience, that of the painter who encounters himself on the easel. That is if by experience we mean what Gadamer describes as "no longer just something that flows past quickly in the stream of conscious life," but an intentional unit of meaning, "a lasting meaning that an experience has for the person who has it." Looking at or experiencing his own painting, Bródy's Rembrandt is in effect remembering: the self-portrait functions for him like the literary genre of autobiography, whose distinguishing characteristic is that though it is objectified in works of art, it does not dissolve in what can be related of it - it "remains fused with the whole movement of life and constantly accompanies it." This is how in Bródy's fiction the work of art disappears as the subject of experience - and becomes, in this perfect transparency, "the consummation of the symbolic representation of life."

It is hardly by chance that what has been perhaps the most influential philosophical conceptualization of high art as understood in the above manner - what Gadamer calls the "art of experience" - is related to Rembrandt, and in particular to his self-portraits: I refer to Georg Simmel's magisterial Rembrandt. In his 1916 "essay in the philosophy of art," Simmel considers the self-portrait as a prototype of the portrait in general, as well as of the representation of man, insofar as in this special case "the external reality of the living model and the artist's reality that dictates from within are given as a unity in consciousness." ${ }^{8}$ There is no room here for a thorough discussion of Simmel's aesthetic of the portrait, which he expounded in a number of essays in addition to Rembrandt. ${ }^{9}$ Suffice it here to point out that Simmel describes the problem of the form of the portrait as a logical "circle whereby the inner life must be comprehended from out of the body, and the body, in turn, out of the inner life."10
He thinks such great portrait art as Rembrandt's is, above all, an experience of totality: it is not only the experience of the unity of the individual presented in the painting with themselves, but also an expression of the "formal unity of perception." ${ }^{11}$ Unsurprisingly, Simmel attributes great significance to the eye and the look as the mediator between inner and external reality, body and soul, the self and the outside world - as the centre point of the Other on which we tend to focus as viewers. While "[i]n the case of people of a more limited life, the gaze fixes exclusively upon the object that they are looking at, at any given moment," the gazes in Rembrandt's (self-)portraits "may each fix on one point, but at the same time they see something that cannot be fixed": the gaze itself is "something spatially and objectively indeterminate," which does not "point at all, but [is] simply there." Now, it is remarkable that Simmel explains the secret of Rembrandt's profundity with the curious loquaciousness of the gaze: "[t]hat the eye speaks actually means that it says more than can be said." The Rembrandtian gaze "pours too immediately out of the dark inexpressible qualities of the soul" to be even called equivocal: in it, individual life as such expresses itself directly. As speech, it is not simply ambiguous: it is positively uninterpretable. ${ }^{12}$

It is consequently no accident that Simmel, the philosopher, like Bródy, the writer, does not discuss specific paintings of Rembrandt (he mentions, at most, one or two now and then). Though he considers every work a "closed, self-sufficient construction," he finds their series vibrant with the same single life: "just as the whole life flows into each moment that is represented as a picture, so it also flows further into the next painting - dissolving, as it were, into an uninterrupted life in which the paintings rarely denote a pause. It never is; it is always becoming."13 It is precisely in the name of the aesthetic totality of the individual, closed work of art that Simmel rejects the well-established practice of art history wherein the pictures are read together through the lens of biography or stylistic history ${ }^{14}-$ implicitly rejecting the reading of Rembrandt by the monographer Carl Neumann as well. Six years later, in 1922, Neumann responded by criticizing Simmel for being normative and ahistorical in disregarding all genealogy and context to treat Rembrandt's late style as absolute, as the realization of the artist's "true" spirit. ${ }^{15}$ 
It may indeed be so that art historians cannot act like writers or philosophers: after all, they need to tackle the historical sequence of works. The most obvious and common solution is to collate each and every painting with the others and embed them in the biography of the painter, as it were, in a kind of framework of "spiritual-intellectual development." There is something irresistibly attractive in this option: accurately dating Rembrandt's self-portraits, ordering them, and finding correspondences with known biographical facts, does without doubt hold out the promise of a readable continuous narrative of the artist's own life, his self-reflective commentary on it. ${ }^{16}$

One of the most illuminating attempts in this regard is Wilhelm Pinder's, who in his 1943 monograph, Rembrandts Selbstbildnisse, applies the wellestablished phrase of "a complete autobiography in visible form"17 to the corpus of the self-portraits. Actually, Pinder proceeds in the spirit of Diltheyan psychological-philosophical hermeneutics. Accurately capturing the development of form and reconstructing the "life connections" help him to read the essence [Wesen] of Rembrandt's character. He identifies his task understanding not so much the works as the author who expresses himself in, or by means of, them. ${ }^{18}$ As a consequence, he too cannot escape the compulsive metaphoric of speaking portraits. Of the Kenwood picture, he writes:

"[Artistry] also speaks in the very incomparable painting at Kenwood House [...], a canvas slightly taller and definitely wider than the late work in the Louvre. [...] This too is distinctly an artist portrait, but it has a completely different ring to it, owing to its apparent different relationship to death. It is as if Rembrandt were withdrawing into the depth of the space, quietly, before our very eyes. There is no relentless introspection; what takes place here is a solemn self-exoneration in the face of death. Here is not only the force of whose presence he must take advantage as it is time do so; rather, it is a force that is already vanishing, has begun to withdraw into silence. This is not this world, captured resolutely and 'for yet another time,' but the lifting of the cover on afterlife, of which the master, a believer, is certain... The easel with the canvas, which is part of the 'close-to-thingness' of the Paris painting, is now missing. The palette is there, but the right hand that led the brush cannot be seen: its world is further and further away from things. The bottom of the picture is dark, but a light space opens towards the sides and upwards, at the height of the head. This is why the whole format is wider. The picture at the Louvre is defined by the upright body of the great artist, so the framing itself is upright. By contrast, the Rembrandt of the Kenwood picture has sunk in himself, and wants to shrink into a new element [will eingehen in ein neues Element]. Like any artist today, Rembrandt himself would of course laugh heartily at such an interpretation. Naturally, this may occur only to the viewers of later ages, and it is subject to refusal as much as to acceptance. For the painter, when he has to say what matters the most to him, the language of the tongue is completely alien: it cannot say that which he silently leads his brush to say. We nonetheless attempt to query his language thinkingly [denkend seine Sprache zu befragen]. It is the language of the simply visible form. A somewhat larger width or height may say what the painter would not want even to hear in words. He cannot say 'afterlife,' but he may enlarge the space around the figure so that it will sink in it: this is how he says 'immersion,' 'entering.' He may lead the light so that the formlike may extend beyond itself, and he has said 'beyond' and 'on the other side.' If we may venture to read it so, the 1660 picture at the Louvre said 'here,' whilst the other says 'on the other side."'19

What I find most notable in this text is what seems a bizarre attempt at translation, whereby the interpreter directly converts certain visual qualities of the given work (at this point, the proportion of figure to background) into a verbal message (while being aware of the pitfalls of the endeavour). Pinder's hermeneutics, however, is only apparently that of the painting. Though he emphasizes the essential dissimilarity of language and image, he does not address the problem of how the image produces its meanings. He registers, for instance, the gradual transition of the lower dark field into the broader and lighter upper one, the progressive loss of the figure's contours, its sinking into the depth of the picture, etc. - but rather than tracing these as the processes of representation that generate an original meaning in the given painting, he immediately compares or collates them with the analogous qualities of another picture, the one in Paris. As we are used to hearing the same voice while one event follows another in the chapters of an autobiography, so we are given the impression that Rembrandt produces his self-portraits in the same single process, painting one 
over the other: one gains its meaning from the other, and only together do they create a world that can be "queried thinkingly." This is what leads the interpreter to the final conclusion: "These two pictures are, once again, a pair complemented by contrast, a Faustian counterpoint." ${ }^{20}$ At the end of the day, Pinder, like Simmel, ${ }^{21}$ considers the painting a transparent film or window which he looks through so that the presence of the Other may become - by the irrational grace of artistic genius - his immediate reality of experience.

\section{ICONOLOGICAL READINGS: THE CHARM OF MEANINGFULNESS}

It is little wonder then that such recent art historiography that seeks to be more rigorously objective keeps a cautious distance from lyricising and speculative interpretations of this kind. It is not only in general that these writings question the scholarly relevance of a discourse that concentrates on aesthetic experience: ${ }^{22}$ they also point out that the expression itself of "self-portrait" is a category that reflects a nineteenthcentury understanding of art, which demands such modern qualities from the relevant works of art which they cannot render - not in the frameworks of their own worlds. What such contemporary wordings as "contrefeitsel van Rembrandt door hem sellfs gedaen," or "het portrait van Rembrandt door hem zelf geschildert," are without is exactly the kind of emphasis on psychological individuality which is in the focus of interpretations like Simmel's and Pinder's: in the seventeenth century, the object of the portrait was still sharply distinguished from the master's hand that produced it. Nor was it uncommon in Rembrandt's studio for his students to paint much-sought-after portraits in his style, to which he then added his signature, his trademark. ${ }^{23}$

It is thus no accident that the recent literature on the painting at Kenwood House is very sparing on commentary on the presence of the portrayed person barely venturing further than Chapman in the passage quoted. On the other hand, with the rise of iconology and semiotics over the past few decades, researchers have taken noticeable interest in a question Neumann, Weisbach or Pinder ignore or treat as marginal: the nature and meaning of the two large half-circles in the background that arch in opposing directions. The presence of the mysterious motifs has been explained in a number of ways, ${ }^{24}$ which could be classified in three groups.

The first group I would call natural, and includes such explanations as Werner Weisbach's, who simply saw ad hoc studio props which were part of the environment, ${ }^{25}$ or Henri van de Waal's, who thinks the circles indicate the hemispheres of a world map on the wall, ${ }^{26}$ which were not uncommon in the backgrounds of contemporaneous portraits and atelier scenes ${ }^{27}$ (Fig. 4). Kurt Bauch also provided further examples in this regard. ${ }^{28}$ The notion was most recently endorsed by H. Perry Chapman, ${ }^{29}$ who complemented it with the idea that read together with the attributes of the painter's vocation, the globe motif may attain further symbolic meanings: on the one hand, it can be interpreted as a vanitas, a warning concerning the lowly worth and transience of things mundane, but on the other, it may have a positive sense as a reference to the spreading of the painter's fame over the world. ${ }^{30}$ The weakest point of these arguments is that while the background seems carefully finished, "completed," these proposed maps lack any cartographic detail, which is unparalleled in any analogous representation.

Another group of the readings consider the circles to be purely symbolic signs. Henriette L. T. de Beaufort, for instance, cites a great many things from Canto 33 of Dante's Paradiso, through Jakob Böhme's visionary mysticism and Persian mandalas, to the concentric circles of Rembrandt's etching known as Faust (B. 270) - everything that could support such occult or cabalistic interpretations of these motifs that are favoured by her. ${ }^{31} \mathrm{~J}$. G. van Gelder provided his assumption with a more solid art historical foundation: he interpreted the geometricizing character of the portrait as an

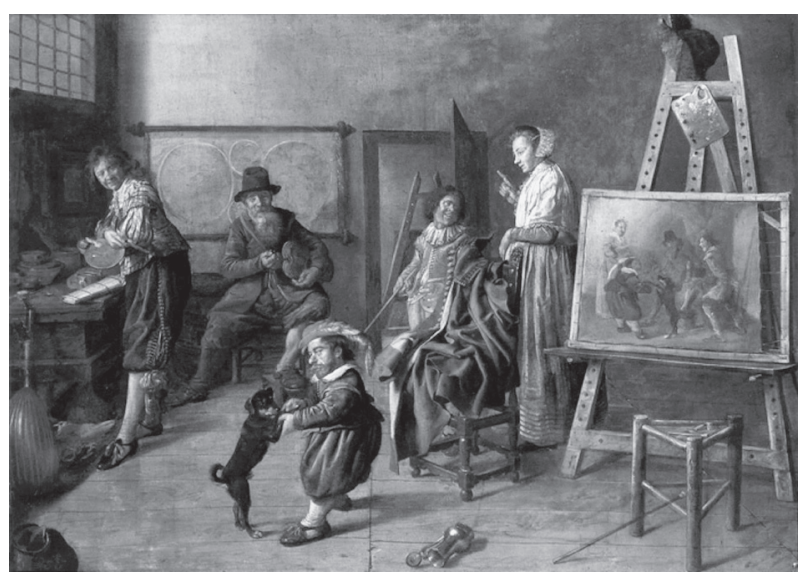

Fig. 4. Jan Miense Molenaer: The Painter in His Studio, Painting a Musical Company, cca. 1658; oil on canvas, $86 \times 127$ cm; Berlin, Gemäldegalerie 
expression of Rembrandt's respect for Aristotle, taking the circles for allusions to the problem of Aristotle's wheels and to the perfection of the Prime Mover. ${ }^{32}$ Finally, I would also include in this group the solution proposed by J. A. Emmens, who in his Rembrandt en de regels van de kunst (incidentally a key study on Rembrandt's iconology) summons the help of the 1624 Padua publication of Ripa's Iconologia. He thinks the left circle stands for the emblem of Ripa's Teoria, while the right for that of the Prattica: each is a female figure with compasses. While theoretical knowledge is represented by the instrument attached to the forehead and pointing towards the sky, practical execution is symbolized by one in the hand, pointing towards the earth: Rembrandt's circles would accordingly refer to the marks of the allegorical compasses. By positioning his own figure between the two ideal marks, suggests Emmens, Rembrandt represents his artistic ingenuity as the mediator between the intellect (ars) and the craft (usus). ${ }^{33}$ In 1984, John F. Moffit complemented this iconological reading, among other things, with one of Vasari's anecdote on Giotto, which leads us to the third group of interpretations. ${ }^{34}$

These attribute the presence of the two half-circles somehow to the work of painting or drawing, and the accomplishment of the artist: they seek, that is, a tighter logical link between the representation of the painter's vocation and the background motifs. The breakthrough in this regard came with B. P. J. Broos' 1970 study in Simiolus, ${ }^{35}$ which does not even deal directly with the self-portrait in question, but concerns itself with Rembrandt's roughly coeval etched portraits of the contemporary calligrapher, Lieven van Coppenol. In the first two states of the first print, called the "Small Coppenol" (Fig. 5), the client is represented seated at his desk, drawing a perfect freehand circle on the blank sheet while being watched by someone who is probably his grandson. The autonomy of the movement is highlighted by the motifs of the compass and the ruler, which are hung up on the wall across: Rembrandt added them to the composition in the second state, and they gain attributive meaning as aids the calligrapher does not need. Broos meticulously demonstrates how the calligraphers of the period, above all the great Jan van de Velde, placed emphasis on refining and representing their technical virtuosity. He quotes at length from Karel van Mander, a theoretical authority, who praised schrijfkonst as the sister of Painting, and compared its best practitioners to Apelles and Dürer. It is in this context that Broos cites a legend Vasari relates about another classic, Giotto,

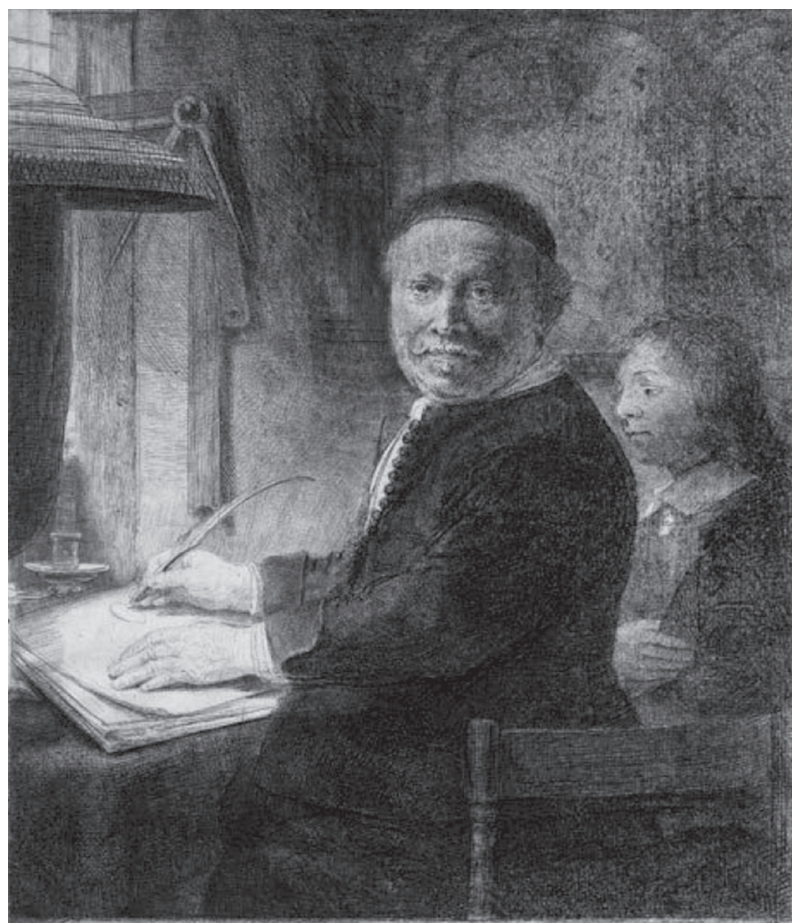

Fig. 5. Rembrandt: Lieven Willemsz. van Coppenol, WritingMaster. The smaller plate, cca. 1658; etching, with drypoint and burin, 3rd state of 6, $258 \times 190 \mathrm{~mm}$

and the virtuoso "O" he drew and sent to the pope. ${ }^{36}$ This story was widely known to artists and art lovers of the Low Countries from the early seventeenth century on, thanks to Karel van Mander, among others. ${ }^{37}$ For Broos, this explains the semi-circular dark field in the background of the "Small Coppenol," which is reminiscent of the half-circles of the Kenwood painting. It explains, that is, why Rembrandt had to replace this geometric motif with a small household shrine in the third state. ${ }^{38}$ He did so, suggests Broos, because Coppenol did not accept the print, considering the reference to Giotto's "O" not an allusion to a paragon of a predecessor, but a snide remark on his own rotund physique. ${ }^{39}$

Now, Broos thinks the mystery of the circles in the Kenwood painting can also be solved with the Giotto story. Barely two years after his conflict with the small-minded Coppenol, Rembrandt uses the motif of the perfect circle again to refer to the sublime side of the story, Giotto's creative genius; the motif serves the mythical-historical legitimacy of his own artistic norms. "Rembrandt took a position diametrically opposed to that of his classicistic contemporaries: in a so-called 'unfinished' painting, he shows himself standing in front of symbolic references to eternity and perfection." "It is in this light that Broos interprets the painting as "one of the rare instances of a direct state- 
ment by Rembrandt concerning the 'Rules of Art'." 41 It is essentially this interpretation that Ernst van de Wetering embraces in his recent monograph on Rembrandt the painter. ${ }^{42}$

The legend of Giotto's "O" is a well-known topos in the literature of art: as early as 1934, Ernst Kris and Otto Kurz cite it in Chapter 4 of their Die Legende vom Künstler, a standard work, as a modern variant of what is perhaps the most important antique narrative on artistic virtuosity, Pliny's account of the rivalry of Apelles and Protogenes in Rhodes. ${ }^{43}$

In 1971 the two stories were discussed again by Hessel Miedema, in a short note in which he contests the basic premise of Broos' hypothesis, viz. that in the period in question the art of calligraphy was considered equal to painting. ${ }^{44}$ Though he mentions that the legend of the painters' contest in Rhodes was also taken over by van Mander for his biography of Apelles, he - like Kris and Kurz - does not relate it to the portrait at Kenwood House. He does cite, however, a long essay from 1967, which the eminent Dutch iconologist Henri van de Waal dedicated to the contest of Apelles and Protogenes, or more precisely, to the history of the modern interpretations of the linea summae tenuitatis that Pliny mentions. ${ }^{45}$ (There is also a passing mention of Vasari's version of Giotto's legend.) Van de Waal is interested in how we are to imagine the large painting that adorned the Roman imperial palace until it was destroyed, with "its vast surface containing nothing else than the almost invisible lines, so that among the outstanding works of many artists it looked like a blank space, and by that very fact attracted attention and was more esteemed than every masterpiece there." ${ }^{46}$ Analysing a large number of mentions in various texts, van de Waal concludes that a "subjectless" painting of three abstract lines could hardly have won the place of honour in classicist theory or in the musée imaginaire of art lovers from the fifteenth to the eighteenth century. This, he claims, is the reason why "modern" posterity was most eager to find out what the legendary painting which the painters took turns to complete represented. Van de Waal points out that throughout the ages, everyone tried to imagine the work as conforming to their own value preferences and interests: around 1450, Ghiberti assumed the famous canvas bore the lines of perspective construction, in 1603 van Mander envisioned classicist contours, ${ }^{47}$ and in 1688 Perrault pictured the fine play of lines as aids in the service of painterly shadowing. Van de Waal calls it the "blind spot" in Western thought on art that it has been unable, right up to the most modern times - including Apollinaire's cubist reading ${ }^{48}$ - to accept that the story, in keeping with antique perspective, is about nothing else but the victory of sheer manual skill and craftsmanship. ${ }^{49}$ Later, in his excellent study, "The Heritage of Apelles," Ernst H. Gombrich could not resist the temptation of adding a further interpretation of the linea summae tenuitatis to the thirty cited by van de Waal: he thinks Apelles won the contest of painters with a highlight effect that relies on the finest balance of light and shadow. ${ }^{50}$

We owe the most complex interpretation to date, a synthesis of the ones mentioned, to Gary Schwartz, who in a short chapter of his 1985 monograph made the first, and to my knowledge, only, attempt at establishing a systematic relationship between the stories of Pliny and Vasari, on the one hand, and the painting at Kenwood House, on the other. The point of his argument is that the antique story on Apelles leaves open the question as to what kind of lines were on the canvas, while the account on Giotto undeniably talks about a perfect circle (a single, complete one); Rembrandt's solution with the two semicircles combines the motifs of the two narratives. ${ }^{51}$ "The artist as Apelles is standing before a large canvas with his own first circle and his rival's answer, in the form of an arc, and he is about to draw an equally fine third circle cutting across the other two. As Rembrandt evokes the scene, we expect the third circle to have the same diameter as the others, and for its centre to lie exactly between theirs."52 By identifying himself with Apelles, a cliché of the time, Rembrandt only adumbrated Jeremias de Decker's poem, published posthumously in 1667.53

Schwartz has another good reason to assume Rembrandt engages in role-playing: he quotes Hoogstraten, who represents Apelles as the master of chiaroscuro, who depicted Alexander the Great with dark hands and a dark head not for lack of skills, but to suggest the power of the blinding lightning he holds. ${ }^{54}$ What with his status and the prevailing taste of the time, Rembrandt stood in need of prestigious historical allies: in the 1660s he was on the way to becoming the eccentric whom Houbraken would describe sixty years later as someone who "is said to have painted over with a brown pigment [taan] a beautiful Cleopatra in order to give full effect to a single pearl." 55 Schwartz thinks this may also account for the unusual clarity of the Kenwood self-portrait: Rembrandt in effect sends a message to his critics, saying he can work so brightly and clearly that no one can find fault with it. ${ }^{56}$ 


\section{THE MOTIF WITH A LIFE OF ITS OWN}

The above-cited art historical interpretations of the self-portrait at Kenwood House seem to be united, in terms of methodology, by their inclination to treat the half-circles in question as simple motifs, to examine them as signifiers independent of their visual context, as it were. ${ }^{57}$

This is in part the reason why purely formal, stylistic explanations have little convincing power. Whether they are taken to be allusions to the virtues of academic creative competencies ("teoria," "prattica," "ars," "usus"), to intellectual and technical talent ("ingenium," "virtuoso"), gracefulness ("facilità"), or to classic predecessors ("Apelles," "Giotto"), the circles are routinely treated as purely symbolic signifiers of the value and concepts that define Rembrandt's identity as creator. Ignoring formal relations is particularly strange in the case of such explanations that trace the meanings of the motifs back to the praxis of the painter and reflections thereon.

This becomes especially conspicuous when we see how specialist literature treats as marginal the question of where - or rather, on what support - the arches in question can be found. Proponents of the "map on the wall theory" naturally have the wall of the studio in mind, or a surface attached to it, yet most descriptions find a vague reference to the "background" sufficient. Those who go about the interpretation on the basis of the legends of Pliny and Vasari are so intrigued by the symbolic meaning itself of the motifs that they usually ignore the problem altogether. This is puzzling because the question of where the work being painted is could have arisen from another perspective as well, as an issue of iconography. If one takes a quick look at the Kenwood portrait, it is at least curious that the semicircles are "immediately" visible, while the whereabouts of the work of art is anything but evident. If Rembrandt appears in such an impressive self-portrait with all his painting tools, how come one cannot see straight away where the piece he works on is placed a compulsory component of atelier pictures, which is present in all other relevant works of his? ${ }^{58}$

Now, during the 1949 cleaning of the Kenwood self-portrait, an elongated, thin, triangular field with an acute angle was revealed in the upper right corner, whose longest side resembles a picture frame (Fig. 6). The slanting line intersects the right edge of the picture at about half its length. On the basis of the painted profile of the simple wooden studio frame, it is impossible to tell which side of the work we can see.
Light greyish-brown brushstrokes fan out from the upper right corner, as if to suggest the wrinkles of a canvas improperly stretched - making the impression the canvas is behind the figure, in front of the viewer, taking up almost the entire background of the picture. The slightly oblique position of what may be the thin edge of the picture may suggest that the canvas, which

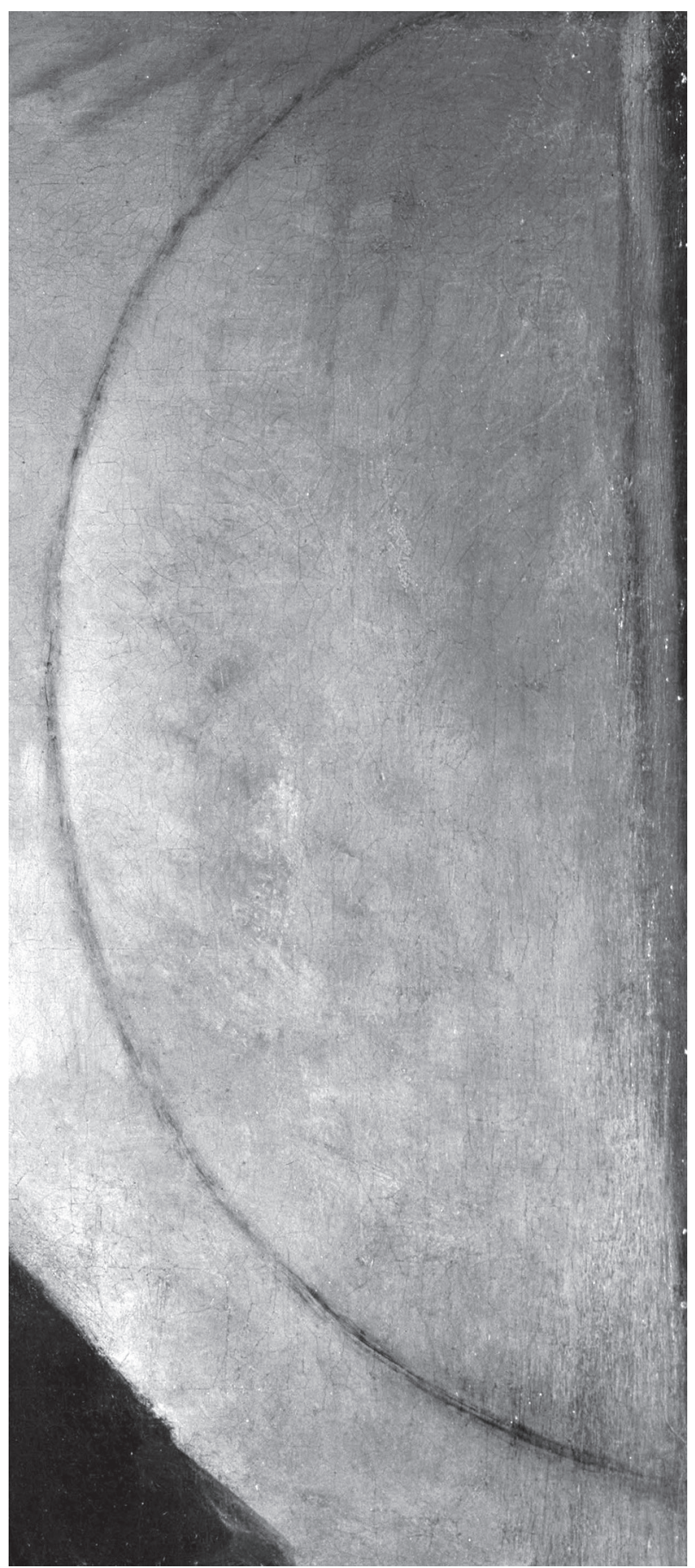

Fig. 6. A detail from Fig. 1 
is primed in a light colour, leans slightly backwards. This argument is undermined by the fact that it is uncommon to represent a work in progress as framed (though it is not out of the question, as we can see in the case of Poussin's 1650 self-portrait at the Louvre, to which we will return below). In such a case the line of the semicircle on the right should follow the light undulation of the creased surface, as a brushstroke on it, yet nothing of the kind is apparent.

Still, it does not seem convincing that we should be looking at the back of the work in progress on the right - on the analogy of the Paris picture in which the wooden panel is marked by a thin, sharply illuminated edge -, as is suggested by the catalogue of the great 1999 exhibit in London and The Hague, Rembrandt by Himself, 59 by the volume of the Rembrandt Research Project (RRP) dedicated to the self-portraits, ${ }^{60}$ and by
Chapman in a more recent study on the uniqueness of atelier pictures. ${ }^{61}$ In this case, the large canvas on the Kenwood picture is to be imagined slanting backwards, towards the painter, while the circles can only have been drawn on the wall - let's admit it, each is more than unlikely. According to the fourth volume of the Corpus, the most peculiar feature of the painting is the unusually light and carefully finished background ${ }^{62}-$ yet the author does not consider what seems the most self-evident: the possibility that Rembrandt fills the background almost completely with the as yet empty canvas, presenting himself before the work in progress, with his back towards it. The only one to see it this way is Gary Schwartz, who, as we have seen, meditates not only on the meaning of the circles, but also on how they are drawn: he also considers in detail what Rembrandt's contribution to the painters' contest should look like.

\section{DIGRESSION: THE FRAMED SELF-PORTRAIT IN POUSSIN AND VELÁZQUEZ, OR, THE PAINTING INDICATING ITSELF}

The motif of the painted frame was not new with Rembrandt: consider only the 1648 Emmaus at Copenhagen $^{63}$ or the famous Holy Family in Kassel. These, however, couple the painted frame with a painted curtain, which emphasizes the institutionalized mode of presenting the work of art, revealing it as a painting. ${ }^{64}$ The frame that surrounds the portrait or is associated with it was also a well-known trope of visual rhetoric. It recurs in notably diverse forms in the seventeenth century, an age that probed the value of images for cognition, their ontological status and reflective achievement. ${ }^{65}$ Suffice it here to refer to the bestknown examples, Poussin's Paris self-portrait (Fig. 7), which he made for Fréart de Chantelou (1650), and Velázquez's magisterial Las Meninas (1657-58) (Fig. 8). The most recent look at the thematization of the parergon in self-portraits was taken by Wolfgang Kemp, who interpreted it as a novel form of critical reflection on the part of the painters concerning the future presentation of the works, their aesthetic survival. "When the frame appears in the ergon, the work, it highlights the fact that the work is not complete and autonomous, and can claim such completeness and autonomy only apparently... If it is constitutive for the work (i.e. necessary for its survival in Western art) to define clearly what is inside and outside it, then those accessories that bring the outside (the environment of the collection, of the atelier) into the inside of the picture will refer to the central difficulties encountered by the modern work of art as it seeks its way between self-constitution and adaptation to the problematic environment: its own future." 66 Kemp analyses the works of Poussin and Velázquez as thematizations of the institutional conditions necessary for their own success in the future, the suitable modes and norms of presentation and viewing. They do so, according to Kemp, by incorporating the "position" - status, mode of viewing, intellect - of the currently absent viewer who will step in front of the painting and will complement, bring to completion, the work in his or her own present, as it were.

As regards the Kenwood painting, it should probably suffice to briefly recapitulate Poussin's solution, which is similar in a certain sense: after all, the famous self-portrait in the Louvre also represents the painter in the studio, immediately before a background of framed pictures. While he omits the tools that refer to the craft of painting (there is no palette, brush, mahlstick, easel or work in progress), Poussin does include attributes of the vocation that impart complex personal references, even theoretical credos. The dark all'antica toga, for instance, is a direct message to the friend in Paris, a reference to the painter's stay in Rome, and hence, his absence; the pyramid-shaped stone set in his golden ring alludes to Alberti' s pirramide visiva and reads like an avowal of faithfulness to the classicist rules of painting; in a partially covered painting in the background, the allegorical figure of Prospettiva, who 


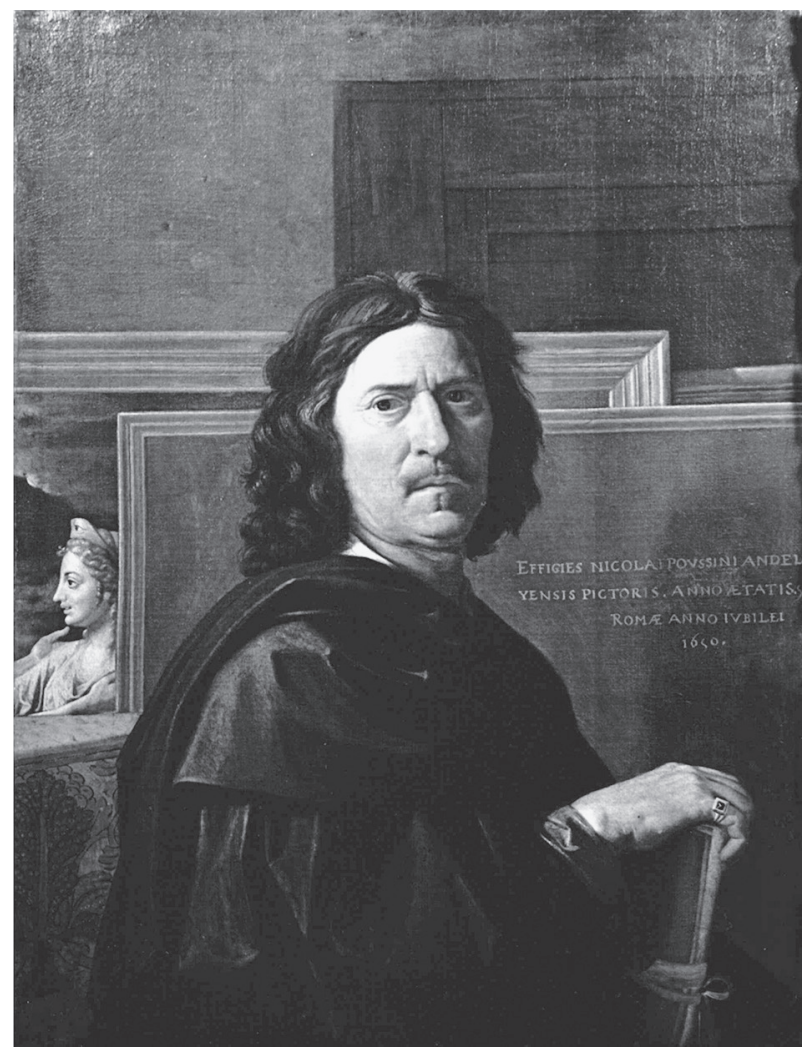

Fig. 7. Poussin: Self-Portrait, 1650; oil on canvas, $98 \times 74 \mathrm{~cm}$; Paris, Louvre

wears a simple diadem, is embracing someone who is cut off by the edge of the picture - is defined, that is, as being absent from the painting. Oskar Bätschmann showed how in the readings and intellectual environment of Poussin and his friends the cult of painting, capable of the miracle of bringing the dead to life, was fused with the cult of friendship and the remembrance of noble friends. All this, says Bätschmann, came to inform the genre of the portrait, of which Pascal already knew that it "conveys absence and presence, pleasure and pain. The reality excludes absence and pain. ${ }^{167}$ By the seventeenth century it was evident that the portrait is precisely the genre that "regularly reveals the ambiguity of imitation, the dialectic of the likeness, and thereby not only acts as a reminder - that is, not only demonstrates death (transience) -, but also reflects itself in this demonstration." 68 The same is suggested by the fact that the figure of the painter appears before a monochrome surface of even finish - a canvas primed in grey, in a golden frame -, from which it is distinct in space, while systematically referring to it. This is achieved partly by the inscription, which runs close to the figure and names him as well, and partly by means of the shadow the figure casts on the canvas and on part of the inscription. This doubling also

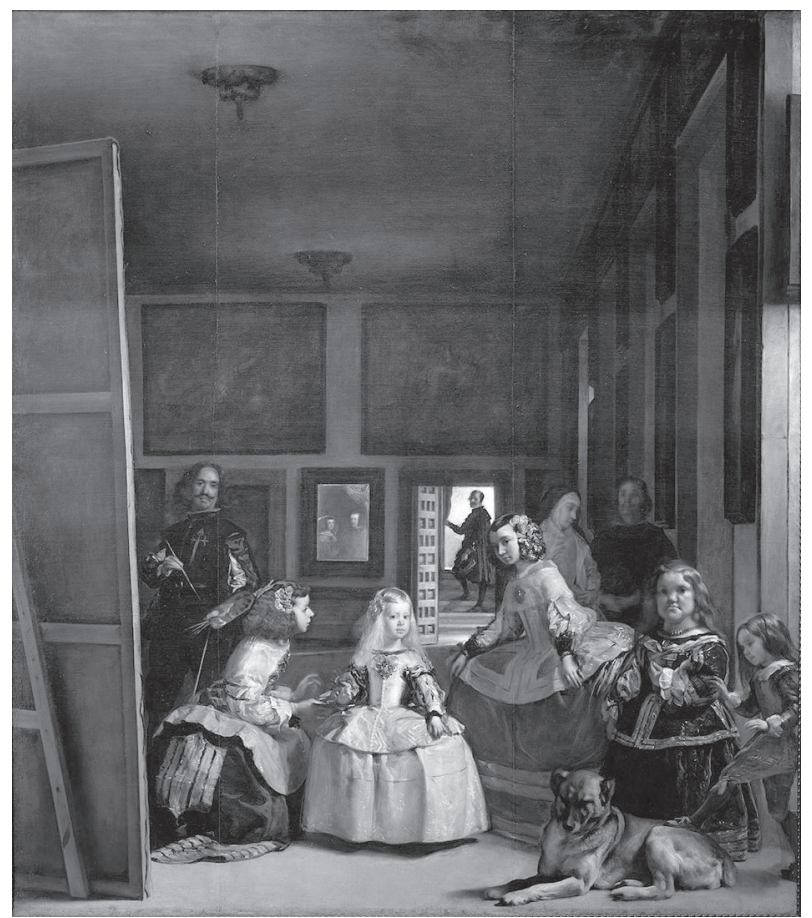

Fig. 8. Velázquez: Las Meninas, 1656; oil on canvas, $318 \times 276$ cm; Madrid, Museo del Prado

refers to the ontological status of the living portrait figure: to the fact that it itself exists only as if it were entrapped between two picture planes - the real and the virtual -, and can communicate with the viewer only in this condition. ${ }^{69}$ Poussin made the self-portrait specifically for Chantelou, expecting him to recognize the incorporated signs of spatial and temporal distance, as well as of the absence of the embracing friend, and hoping he would be able to fill the voids with himself, as it were. Poussin's Self-portrait is thus a paradigmatic example of the classical work of art: its parergonally open structure awaits a future, competent viewer who as a worthy partner of the creator can enter the work, realize its instructions, understand its references, and reciprocate the gestures - one who will round off the work with their living, communicative presence, and thereby restore "the time [that is] out of joint." Restoring the institutional context of the work also contributes to this: Chantelou knew what his responsibility was, and exhibited the work as the finest piece in his own collection, which greatly pleased Poussin: "The place you provide for my picture in your house lays a great burden on me. You will preserve me in the same worthy manner that Virgil's likeness is preserved in the museum of Augustus. This will bestow on me the glory belonging to the dukes of Tuscany, as if my self-portrait accompanied those of Leonardo, Michelangelo and Raphael."70 In the eyes of Kemp, Poussin 
is a classical artist in the sense proposed by Valéry, insofar as in his case classicism goes hand in hand with a readiness for criticism/self-criticism. Poussin sees painting not "only and always as a work of art, which offers itself to the future as an integer, a self-fulfilling monad," but "as authority and criticism, the anticipation of a future conceived on the basis of a critical tradition, on the simultaneous consideration of conditions and consequences." 71

In this sense, Rembrandt's self-portrait at Kenwood House is certainly not a "classical" work. Not as if he had not aspired to be included in the Medici gallery of self-portraits in Florence, to appear among the uomini illustri, ${ }^{72}$ and as if it left him cold whether his works were hung properly, or viewed appropriately, from the right distance..$^{73}$ But then, at first sight, his picture is far "simpler" than Poussin's or Velázquez's. It is as if he knew nothing of the problem of form in the "classical" painter self-portrait, which had crystalized precisely in that period, the mid-seventeenth century. By this convention, when the painter appears as a painter, i.e. in the act of painting himself, he is by necessity reflecting on the relationship between the work already painted and being viewed, on the one hand, and the virtual painting it represents, on the other. Velázquez is of course more enigmatic in this regard than Poussin: by turning the back of the work in progress towards the viewer, he produces a paradoxical metalepsis of passage between the world before and the world behind the frame. ${ }^{74}$ In his turn, Kemp suggests that the achievement of the work does not end with the production of an illusion, however complex. "If we celebrate [Las Meninas] as his main work (not unlike its first addressee, the king, who hung it in his office), then we are paying honour to the most brilliant achievement of which painting was capable, above and beyond the scope of the court portrait. The greatest feat of this achievement is that it does not - indeed, cannot - depart from the conceptual and existential contexts of the court, as it has visibly integrated them." 75

Nothing in Rembrandt's self-portrait at Kenwood House implies such reflections on the "critical self-fulfilment" of the work and on its historical fate, a constellation that could be called, after Kemp, Rembrandt's "teleology" of painting. Nevertheless, he cannot be said to ignore the problem of form mentioned. In contrast to Poussin and Velázquez, however, he follows a strategy of reception aesthetics that generates the paradox of a painting that represents/indicates itself. It does not seek to solve the task by manifestly indicating the presence of certain elements, while designating others - no less manifestly - as absent. Rather than appealing to the critical mind or intellectual understanding of those who can appreciate "classical" art, he sets in motion the dialectic of the visible and the invisible by playing with the viewer's attention, the automatisms of seeing. To anticipate my conclusion: by minimizing iconic difference, Rembrandt comes up with a "picture within the picture" solution that Genette would probably call metaleptic embedding, in that the visibility of the real painting almost "coincides" with what it conjures up as represented. ${ }^{76}$ In other words, Rembrandt seeks to divide the gaze, so that it can simultaneously realize two kinds of visibilities which are layered one upon the other. Accordingly, the main question of the interpretation is this: how does the painting elicit this "double vision," and what is the benefit of this experience from the angle of artistic cognition?

\section{THE PHENOMENOLOGY OF THE BACKGROUND}

Since the matter at issue is the conceptualization of visual experiences, in the following I will attempt to grasp the Kenwood picture as a viewer, in the mood of aisthesis. What I seek to do is to concretize the abovementioned "play" of the painting, to reveal the concrete potentiality of what Gottfried Boehm calls the iconic difference, ${ }^{77}$ and which can only be realized in the proactive process of observing the work. Imdahl offered the term "seeing seeing" (sehendes Sehen) to describe the work wherein, instead of naively taking notice of the visibilities that are made available in the picture directly, immediately, we look for logical links that the work does produce, yet refuses to make evi- dent straight away. This then is a process of uncovering and cognition, not an arbitrary act, and we must consequently be critical, and question the automatisms of how we look and attribute meanings - above all, we must pay attention to the painting, we must follow the distinctive instructions and encouragements with which it orients the activity of the viewer. In the course of this cognitive work I will abide by Gadamer's supposition, according to which the work of art is like a game, which is to say that we as recipients should not follow the dictates of our personal taste but should join the "game" offered by the work of art, and as all good players, should accept/follow the given rules to 
become active participants. ${ }^{78}$ What is at stake in the game is cognition - the new experiences and knowledge we may gain while being involved in the "events" of the painting.

The starting point of my reading is a principle of phenomenology, viz. that the visual experience begins with something that is in evidence - something that catches the attention and encourages the observer to further activity. ${ }^{79}$ In this sense, the painting is necessarily the scene of showing, of arousing and controlling attention: painters are experts in making certain parts of their pictures emphatically noticeable, others less likely to stand out. This economy is there in every painting, but only a few make us conscious of it as this very game.

Seen from this angle, it is evident why every one of the cited readings tended towards one of two directions: both the psychological evocativeness of the personality represented and the enigma of the "circles" elicited especial interest as they are very much in evidence. At the same time, the whereabouts of the work in progress is not thematized in research because its presence is not so obtrusive as to enforce this kind of attention. Writers and philosophers are interested in the presence of the personality, iconologists in the meaning of the symbol: as a result, practically no one takes notice of the canvas itself, which in their eyes vanishes in the grey area of the meaningless background..$^{80}$

Yet the sight of the circles is without doubt conspicuous. We perceive different qualities: the "painted" figure requires a type of glance that is different from that called for by the "drawn" circles. With regard to the former, Ernst van de Wetering, the author of a study on Rembrandt's self-portraits in Vol. IV of the Corpus, accounts for such features as the hasty, sketchy marks of the cap or the painting tools by referring to the beholder's share, Ernst H. Gombrich's famed category of the psychology of art from Art and Illusion. ${ }^{81}$ Gombrich thinks such forms are there for the viewer, provoking her to complete with her imagination what the painter presents to her as consciously arranged painterly patches. A great deal was already known in the seventeenth century about this practice of visual projection, and van de Wetering does quote Samuel van Hoogstraten, a student of Rembrandt, who in his 1678 treatise, Inleyding tot de Hooghe Schoole der Schilderkonst discusses, among other things, painted and drawn forms (including "roundish, square, triangular, longish or oblique" forms) that imitate the distortions of looking through half-closed eyes, or at things at a great distance - looking, that is, without paying atten-

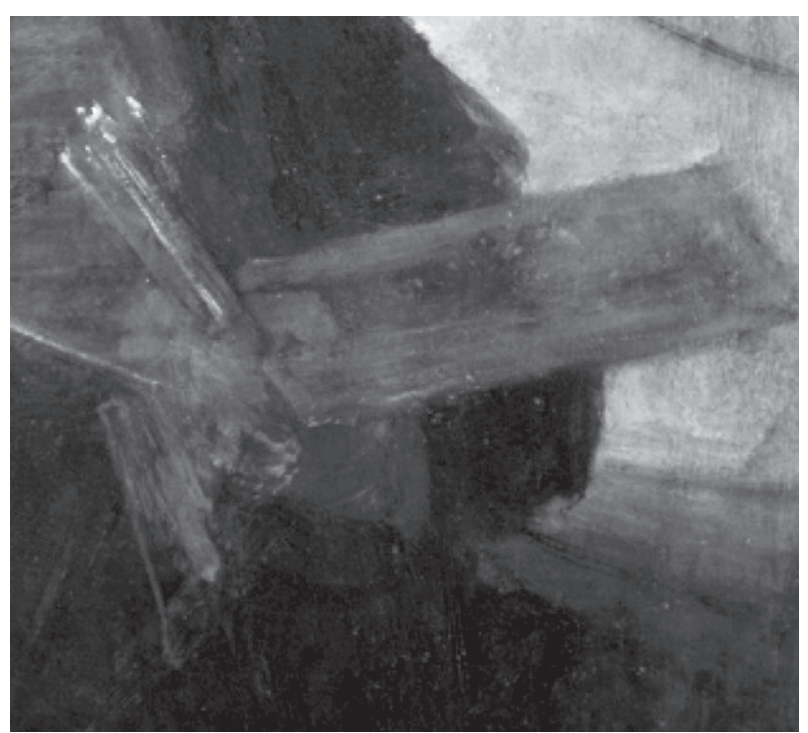

Fig. 9. A detail from Fig. 1

tion to detail. ${ }^{82}$ Van de Wetering finds these passages "highly relevant" for the Kenwood self-portrait as well, as regards particularly the painting tools and quasigeometric formulae of the contours of the lower body. He also cites another passage from Hoogstraten, which throws some light on the different techniques used for the head and the face: when a surface is noticeably grainy, wrote Rembrandt's student, the human eye will perceive it as if it were closer. Hoogstraten must have learnt much about the function of kenlijkheyt (the perceptibility of surface qualities) in perception from his master. Van de Wetering claims Rembrandt used the same effect in the illuminated parts of the face in the Kenwood self-portrait, where "there are countless fine indentations and scratches visible [...], the fine traces of the stiff hairs of a brush," ${ }^{83}$ which suggest the irregular wrinkles and pores of aging skin. Van de Wetering considers this less of a stylistic mark of the late period than an ad hoc choice that served a specific mimetic purpose: he cites an example (whose authenticity, incidentally, is contested in the literature), in which the old Rembrandt used a very fine mode of painting to suggest the firmness and flexibility of the young female model's skin. ${ }^{84}$ However, van de Wetering does not really investigate the relationship between the head and the face, on the one hand, and the hands and tools, on the other, i.e. the fact that the former are composed for close, while the latter for distant, viewing (Fig. 9).

The painting is evidently expecting a viewer who is willing to enter the game on offer - who is ready, that is, to experiment with finding the ideal point before the picture whence the figure will emerge for her in its living plasticity. For this to happen, the 
viewer should keep her eyes on the most vigorously defined point of the painting - the right eye, marked with a conspicuous black -, so that it remain in the fovea of her retina, the point where visual acuity is highest, while changing her distance from the picture plane until the figure suddenly "coheres" in her eyes. ${ }^{85}$ This would account for the difference between the two rouw modes of painting, the dissimilarity between the finishes of the face and the lower half of the picture: Rembrandt was consciously building on the difference of foveal and peripheral vision. We see as much of the painting tools as he could see while fixing his eyes on his own left eye in the mirror. It is as if not all points of the picture required attention of the same intensity; as if the picture represented the complete field of view.

Whatever the case may be, finding the accurate focal distance demands a heightened level of aesthetic consciousness from the viewer - and cannot but lead to a recognition of the link between the "magic" of the optical image and the technical precision of the brushwork. Gombrich cites a number of historical documents to prove that by the seventeenth century, examining the "magic of the brush" had become part of connoisseurship, and could only be performed by systematically changing the focal distance. ${ }^{86}$

Now, without realizing this elementary visual dialectic, the alternation of illusory vision and purposeful technique, the more complex plays of the work cannot be set in motion either. Including the one that derives from considering the figure in isolation, and together with the (back)ground. Note, for instance, how the unusually light background gradually becomes darker in the lower third of the picture, and the contours of the body become increasingly blurred until they dissolve in the dark ground. In the upper parts, the figurative visibilities (the torso, the head, the cap, and particularly the circles) are very distinctly separate, both from each other and the supporting ground. What is, as a rule, described in the literature as the "unusual lightness" of the background of the Kenwood self-portrait, can also be deemed an intensification of the dif- ference between "figure" and "ground," which invests each, one through the other, with the emphatic appearance of an individual identity. There is a reason why the almost undivided plane of the background and the head are considered the "most completed" parts of the painting: they are "finished" in relation to each other - one against the other, as it were. The plasticpainterly density of the head, its richness of traces and saturation of facture, can produce the presence of the figure only together, or in contrast, with the no less dense, yet finely finished background, its planar effect. All this is beautifully obvious where the luxurious, almost palpably wrinkling textile of the whitely shining cap clashes with the abstract, uniform neutrality of the background. However, as we go down, both lose their massive opacity, gradually and evenly. Not only are the contours dissolved, but the surfaces also become looser. The visual contamination of figure and ground first leads to the inconsistent use of contours as in the palette -, the melding of things and surfaces, and eventually to their complete indistinguishability. Examples of the latter include the objective illegibility of the overlapping paint patches of the hidden left hand, or the total darkness of the lower right corner. The conditio sine qua non of any picture, the elementary contrast of "figure" and "ground," which at the top manifests itself in the formulaic, graphical purity of geometric lines and a white ground, becomes utterly impossible to identify. Of course, the process can also be read in the opposite direction, as the gradual separation of the body from the background, its plastic emergence, as a result of which it positively seems, by the height of the asserted focal point, the head, to lift from the tilted work in progress behind it, itself progressively "solidifying" into a self-identical thing. The motifs then are not simply what they seem - no "this here is the figure, that there is the canvas" -, but become self-identical or lose themselves in the process of the picture, in the iconic contrasts of their mutually dependent visibilities, the plays of figure and ground, space and plane, contour and tone.

\section{MARKING MARKS, TRACING TRACES}

The role of the hand that moves the brush is also directly thematized in the painting in question. X-ray radiography has revealed that Rembrandt repainted the first state he painted before the mirror, in which he still raised his right hand with the brush to the work in progress on the side ${ }^{87}$ - while replacing the left hand, as already mentioned, with a motley of blurry paint patches. ${ }^{88}$ In her important monograph on Rembrandt and the problem of working in the studio, Svetlana Alpers claims that with this selection of the painter's tools, Rembrandt marks his own hand as a tool: what the raw manner aims at is not the expressivity of the 
movement of the brush, but a construction of the body ("the hand may be a palette, a mahlstick, or even a brush") that metonymically represents "a certain action of the hand." 89 Alpers describes this action of the hand as touching in quality, and through the analysis of several examples, she characterizes it as the working method of a "failed sculptor," who keeps turning his paintings into something "relieflike and solid." notable, however, how she ignores the circles and the canvas - abstaining not only from taking a position in the arguments about the meaning of the circles, but also from recognizing the marks of a different "hand action" in their modelling.

Rembrandt plays on a variety of registers, as we have seen. In the case of the monochrome circles, for instance, he seeks to hide the real traces of his brush in the vision of the simple "drawing." As if he were a fijnschilder, here he works to suppress the same dialectic visual experience which in the instance of the figure or the tools he makes such an effort to bring about in the viewer. While in the latter he practically provokes us to uncover the mark of the hand, the graphic formula of the background makes it unnecessary for the beholder to repeatedly change her focus - and her share. Why indeed should we study at close range a simple, regular line, as if we were expecting to uncover the magic of devilish technique?

Harry Berger Jr. recently proposed to read the plastic qualities of the picture surface as texture, i.e. a collection of meaningful signs. Surprisingly, in his discussion of the Kenwood self-portrait, he does not realize (like Alpers) the evident (though not glaring!) difference between the various "touches" that make up the rouw figure and the fijn background. ${ }^{91}$ This is surprising, because if anywhere, in this monumental self-portrait, which also represents the dignity of the vocation of the painter, the artist can evidently expect his viewer to distinguish his own personal touch as such from that other one, which he may have painted, but which - precisely in its linearity - is emphatically detached from this "personal" one. This too should encourage us to consider the circles not in isolation, but in conjunction with the canvas as support, and the figure as something that is plastically detached. We can attribute meaning to the circles only if we are willing to observe them in their visual context, i.e. in the concrete system of their iconic differences.

We saw how the interpreters of Pliny's and Vasari's legends on painters also believed Rembrandt's circles to be the marks of the hand of Apelles/Protogenes and Giotto - but what they saw in them were the symbols of brilliant painters' hands, and not the indices of painterly presence. Whereas it is in fact the latter that links the two narratives to each other and to Rembrandt's painting. The two are then worth reading again, and reading together, for a more accurate interpretation of the work's message.

I would like to highlight three circumstances in the two narratives, which can be profitably employed while looking at the self-portrait at Kenwood House. One is the abstract quality of the marks made by the painters; the second is that the marks of their hands serve to identify the person of the artists; and finally, a lay person is given a key role in each story, one who is decidedly not competent in questions of art.

Let us start with the old woman in Pliny's tale, who is an eyewitness to the contest of the painters in Protogenes' house: she is the one who asks the unknown guest to identify himself, and this is what prompts Apelles to answer not by providing his name, but by leaving an abstract mark of his hand (linea ex colore...summae tenuitatis) on the work in progress. Protogenes then follows suit: the two can be said to be communicating in the language of their profession, yet "over the head" of the old woman. It is as if they were avoiding each other so that they can perform a game before the old woman which she is not let in on. They only meet in person when they have finished the contest (of which only they can be the judges). What the whole thing serves is the differentiation between those who are competent and those who are not, as well as the demonstration of this distinction. This is why the two painters subsequently decide to keep the jointly produced work, so as to allow everyone, "but in particular painters, to marvel at it" (...omnium quidem, sed artificum praecipuo miraculo). What van Mander himself emphasizes in his commentary on the locus classicus is that "those who had an understanding of painting were very much astonished and amazed by it." 92

Now, in this and similar stories by Pliny, the professional rivalry invariably takes place before the public, and the uninitiated audience regularly fails when trying to give a ruling. The final judgement is always passed by those in the know. To accurately interpret the antique stories, we must note that in the readings of posterity, the motif of the contest tended to eclipse that of the mutual respect of the artists, which was underlined even in van Mander's commentary. (Apelles, for instance, is said to have bought up Protogenes pictures out of professional solidarity, so that he could hike up their prices by means of his own renown. $)^{93}$ The joint manipulation of the experts is at the expense of those 
- in this case the ignorant inhabitants of Rhodes - who pass judgements superficially, on the basis of fame alone, but cannot tell the difference between two lines, are not knowledgeable about art.

The case is very similar in Vasari's narrative. Giotto's "O" is an abstract sign again, which identifies the painter as a genius of drawing. Let us see the story as rendered by Karel van Mander (as this was, after all, most certainly the form in which Rembrandt knew it):

"Giotto was witty; he took a sheet of paper and holding his arm against his side to act as a compass, he drew on it, with a turn of the hand, never moving his arm, a circle so perfect that it was a wonder to see. Having done this, he gave it to the courtier with a grin, saying: there is the drawing. Whereupon the courtier, thinking himself made fun of answered: am I to have no other drawing than this? This is more than enough, said Giotto, show it to the Pope with the rest, and you shall see whether or not it will be appreciated. He left ill-satisfied. When this drawing came before the Pope among others, and when he had been told in what manner it was drawn by Giotto, without a compass and with a stiff arm, the Pope and his many judicious courtiers understood that Giotto was the best painter of his time." 94

Curiously, none of the interpreters took notice of the conflict that arose between the painter and the courtier, even though van Mander emphasizes it in the title of the passage (Giotto treckt een rondt, in platse van teyckenen); the uninitiated envoy of the pope is not satisfied with the circle and would rather take something else, a "fully developed," "lifelike" picture. He has to leave disappointed because Giotto (like Apelles and Protogenes) entrusts the representation of his talent to an abstract sign which only the initiated (verstandighe) can interpret. The courtier does not understand that one can tell real art not by the illusion created by the work, but by the ability to perform. Those who do know, because they can read the abstract language of technique, will be more than satisfied (meer als genoech) by the mere mark of the hand. Giotto, in other words, knows that the evidence he must provide of his talent to those who are really competent should differ from what he enchants the uninitiated with. Nor is this story then solely about technique becoming "an end in itself"95; it also concerns the possibility to communicate artistic knowledge, as well as its publicity.
This is why the courtier, like Pliny's old woman, is given a key role in the story. Their function is no more than to bear witness to the fact that the marvellous lines were drawn by the painters themselves - the fact that the lines can indeed be identified with them. They are eyewitnesses who can be believed because they were there when the work of art was created, and because they are impartial: they will not judge the work because they do not look upon it as art. They are credible eyewitnesses without being viewers. They could be called the ideal principal witnesses of a modern positivism $^{96}$ that considers only the unintentional marks of the artist's hand as proof for the authenticity of a painting. Is this not what the scientistic researcher does when treating visual marks as sheer positivity, assuming they will allow her to access the work in the pure presentness of its creation? Is it not naive on her part to assume that the attribution, the dating, and the restoration of the "original" can be carried out more accurately if she concentrates more on the physical facticity of the work of art, and less on the distinctive working of the image? Does she not, deep down, long for the simple obvious truth of the old woman or the pope's courtier; a truth that cannot be altered by her taste, interests or prejudices, one that allows her to say with scientific objectivity: "this is a real Rembrandt"?

From all of which at least two things follow. To be knowledgeable about painting is to know that every picture has an implicit question which we as viewers must be able to answer. Apelles sends a task to Protogenes, as does Giotto to the pope: they tell the other to observe the qualities of the touch, marshal their knowledge, compare the work with those of others, consider how it was made, etc., to understand in the picture precisely the message: "It was I who painted this." And of course they also expect an answer: leaving a mark has its stake, as its success must be acknowledged by the other. Both stories involve an exchange of messages, in which the knowledge of paintings appears as competence at playing - and both stories are also about the success of this game, mutual understanding: the two painters are amicable when they eventually meet in the harbour of Rhodes, and Giotto wins the Rome commission from Benedict XI.

The knowledgeable viewer must also know that the work exists in time: she must know that looking at the picture, she must decode a message that by necessity speaks to her from the past. In other words: she must not identify the painting with the momentary immediacy of its effect. The difference between the uninitiated and the competent viewer could also be 
described thus: while the former understands the picture as a mere likeness (as an icon), the latter knows that it is also to be looked at as the marks of painterly procedures that are to be read after the event (as an index). Since an icon is a sign based on likeness, even the naive viewer can assess the degree of similarity instinctively, immediately, because she will spontaneously treat the portrait as concurrent with what it represents. Whereas, points out Rosalind Krauss, the key to the effect of the indexic sign is time: the distinction of the presence of the sight from that of the indexed, which was present in the past. ${ }^{97}$ When admiring its lifelikeness, the naive viewer perceives the painting in its presentness - yet this is a trap, which constantly threatens even the most competent expert. The hero of another one of Pliny's stories falls into a trap of this kind: the famed Zeuxis loses his contest against Par- rhasius because even though he proves his mastery with the grapes he paints, the thirst for victory makes him impatient (tumens flagitaret) when he approaches the curtain to draw it aside. It is the automatism of his reaction that is of interest here, which is after all not different from that of the birds which start to pick at his lifelike grapes. Parrhasius wins the contest not because he can produce an illusion that is more perfect in itself, but because he is aware of this playful nature of the painting from the start. Nor is his painted curtain more than an intellectual joke, a witty reminder of how the parergon cannot be circumvented, a warning for the naive Zeuxis of the permanent play of the picture, and of his task as a viewer, critical distinction. It teaches him that immediacy makes one blind to the actual achievement of the picture - that every picture demands its own time.

\section{GAME OF FRAMES AND PERFORMANCE: THE CURTAIN OF OBVIOUSNESS AND PULLING IT ASIDE}

If, in the light of the above, we give credence to the assumption of Gary Schwartz, who thinks Rembrandt presents himself in the self-portrait at Kenwood House as a modern Giotto/Apelles who enters the world-historical contest of painter genii, we might, by way of closure, ask: by what mark of his hand does he intend to claim victory? Schwartz is quick to provide an answer: Rembrandt "is about to draw an equally fine third circle cutting across the other two [... and] we expect the third circle to have the same diameter as the others, and for its centre to lie exactly between theirs." That of course is possible. Schwartz, in any case, has no more "evidence" than the visual obviousness of the view: the regularity of the symmetrical forms, and the possibility to geometrically construct the third circle. But does he not fall victim to the phenomenal lifelikeness of the atelier portrait when he can imagine the victorious touch as a figure that can be identified unambiguously? Does he not yield to the charm of pure presentness when he imagines the mark of Rembrandt's hand as not yet visible on the half-finished canvas? Does he not judge according to the normal routine of seeing when he considers evident only what can be seen immediately, or whose empty place he can point at, as it is absent for the time being.

In view of the above, I think it would lead to more profound insights if, instead of some future "third circle," we considered Rembrandt's own head as the mark he contributes to the contest. Does he not enter the contest by doing what the mythical predecessors did: identify himself with the marks of his hand, and make these marks, in Pliny's words, escape being seen (visum effugientes), ${ }^{98}$ while instructing the addressee to see them and recognize them as meaningful? Is not the viewer to identify the marks of Rembrandt's hand in the mass of abstract marks, a devilish arrangement of pigments, brushstrokes and factures? Is this not the point of inserting his mark between the two "alien," evident marks, ${ }^{99}$ his own being both evident and not?

Does not the painting challenge the viewer, requesting her to suspend the automatism of the gaze, to postpone, as it were, the look - to treat what/who she immediately sees not as a self-identical given that is offered as something complete? Does it not request her to recognize the painting as a game of identities?

To recognize the game is to play it; it is giving it time so that it can take place. As good players, we must follow the hide-and-seek of the picture; we must not immediately fall for what it flaunts, but must seek out what it hides behind the curtain of obviousness. To put it differently: we must consider it a performative which waits to be played out, and which expects the viewers to facilitate the performance with intense attention, a critical mind, consideration and reflection. In short: the picture requires us to look at it as something in which we want to see - want to experience - something.

Let us consider, for instance, the barely discernible slanting line of the thin wooden frame. We have seen 


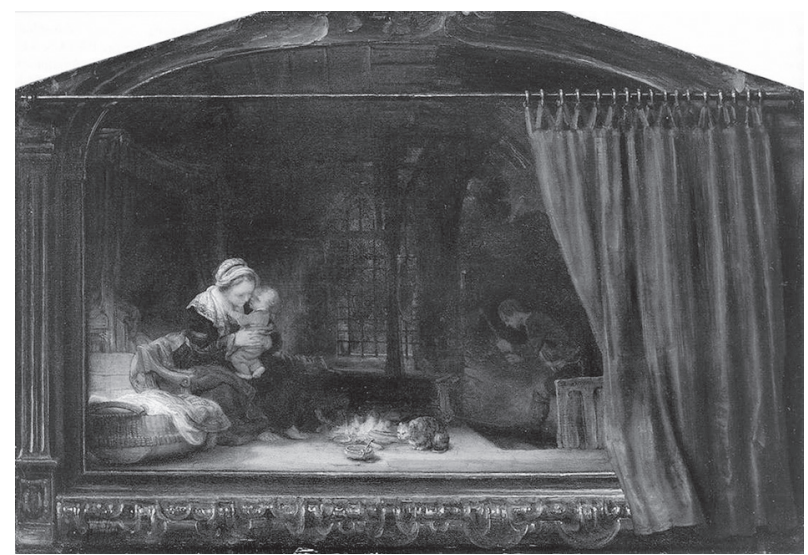

Fig. 10. Rembrandt: The Holy Family with a Curtain, 1646; oil on wood, $46.5 \times 69 \mathrm{~cm}$; Kassel,

Staatliche Museen Kassel, Gemäldegalerie Alter Meister

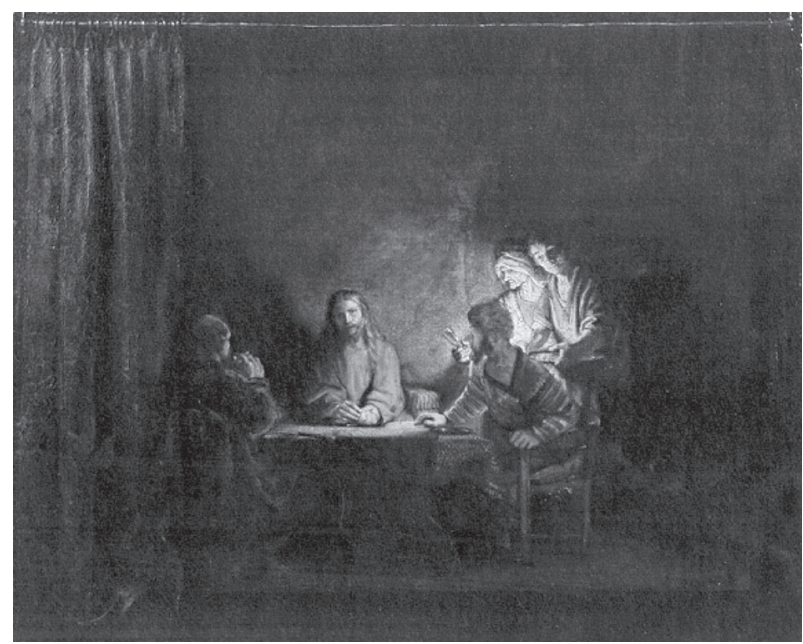

Fig. 11. Rembrandt: The Supper at Emmaus, 1648; oil on canvas, $89 \times 111 \mathrm{~cm}$; Copenhagen, Statens Museum for Kunst

how refusing or not being able to remove its ambiguity led to inconsistencies in the interpretation even in specialist literature. I have already made a passing reference to the fact that this is not the first occasion in Rembrandt's oeuvre when the painted frame has appeared. In The Holy Family of Kassel (1646) (Fig. 10) or the Emmaus scene at Copenhagen (1648) (Fig. 11), the motif - complemented with the curtain - still aims at a clear distinction between ergon and parergon, at making the viewer conscious of the fact that the picture both shows a "world," and indicates an "object-ofa-painting." Rembrandt plants in these pictures two kinds of performance instructions for the viewer, which, however, are openly contradictory: the viewer cannot simultaneously be a truth-thirsty eyewitness of the divine revelation of the ergon, and the connoisseur who can appreciate the secular work of art marked by the parergon. The broad frames and the curtains

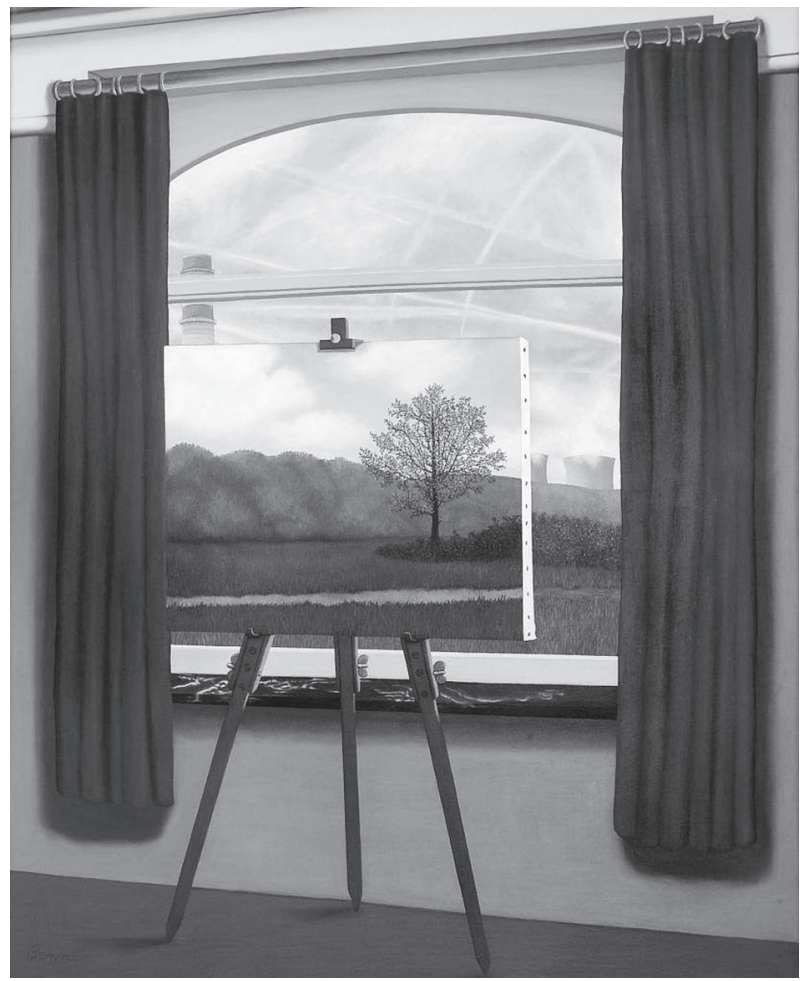

Fig. 12. René Magritte: La condition humaine, 1933; oil on canvas, $100 \times 81 \mathrm{~cm}$; Washington D.C., National Gallery of Art

pathetically drawn aside are emphatic in these cases so as to make the perception of, and the reflection on, the threshold ineluctable; they force themselves, so to speak, on the gaze, which otherwise routinely ignores everything that is perceived to be lying outside the world of the picture. With its parergonal structure, the painting stages itself, as it were - yet the play will not work until the viewer recognizes these roles, performing and becoming conscious of the conflict that exists between the identities encoded in them. ${ }^{100}$ At any rate, these paintings seem to be thematizing the status of the picture and the quality of the recipient's presence, i.e. the same general conditions of the operation of painting as a social, public institution that Poussin and Velázquez look into in the cited "framed" self-portraits.

It is then all the more curious that in the selfportrait under discussion, whose ambitions are no less representative, Rembrandt starts playing with hiding the painted frame itself. Now, instead of doubling the picture plane in an open, reflected manner, the barely noticeable edge of the painting enigmatically divides its uniformity. It is a question of very fine proportions. Rembrandt, like Poussin, could just as well place the fictitious empty canvas behind his own figure so that its edges allow a better view of the background, 
such as the back wall of the studio. Should this be the case, the accurately delimited work in progress would be easily identifiable, as in so many atelier scenes: it would not require interpretation. By contrast, Rembrandt not only makes the canvas extremely large, but also places it so close to the picture plane that the two overlap almost completely. ${ }^{101}$ By pushing the frame to the periphery of the picture field, he separates the light canvas from the dark corner of the studio (i.e. the two entities that are separated by the thin line) in a way that reduces their iconic contrast to a minimum. "Too much" can be seen of one, "too little" of the other, for either to have an "evident" identity. The unaccented edge thus fails to evoke a contrast in depth between an object brought close up, and the space behind it; rather, it follows the edge of the real canvas, and it is vis-à-vis the latter that it conjures up the spatiality of the tilted object. Though even this difference results only in a minimal contrast effect, as both edges (and the thin gap between them) remain marginal, it somehow still gives rise to an unsettling uncertainty about the possibility of distinguishing the fiction and the reality of the picture. "Mais où est donc le tableau?" we may ask in the manner of Théophile Gautier who enthused over Las Meninas ${ }^{102}$ - though we would give voice not to our wonder over the painterly magic, but to an experience of perplexity. Even such an apparently perfectly unimportant - though very accurately positioned - motif is enough for Rembrandt to bring about a crisis of our convention-driven gaze, which seeks to identify/name things at all costs.

However, the game with the identity of the frame is no innocent pursuit. There is something subversive to it in that it questions, almost imperceptibly, the same established signs, codes, and collective certainties that form the foundations of his own personal representation, his expectations for the continued existence of the work, as well as the mission and future of painting as a social and public institution. What Rembrandt's tricks undermine most is the status of the viewer, in whom the parergonally open work should come to completion - in accordance with Poussin's or Velázquez's "classical" teleology of the art of painting -, and whose position he himself still tried to define precisely in the cited works at Kassel and Copenhagen. The integrity of the self-portrait at Kenwood House is subverted, rather then restored, by the ambiguous instructions that the "frame game" provides as to the position the viewer should adopt, and what she should see (Fig. 12103).

Is not the elusive frame then Rembrandt's own linea summa tenuitatis? Is it not the razor-sharp, though self-concealing, distinction between showing and indicating, which places, practically inconspicuously, the personal presence of the painter between the quotation marks of the picture, and passes it on to posterity thus? Do not these quotes, left open indefinitely, encase Rembrandt's teleology of painting? Missing which, do we not miss the self-concealing difference between the two kinds of speech encoded in the picture? Because when we give in to the temptation of evident truth, the charm of presence, we will likely end up hearing only the confession of "it is I who paints here," and ignore the eerie emptiness of the marks left to us from the past: the signs of absence, whose historical message we can decipher, after a fashion, only while wandering in the performative labyrinth of the painting: "it was I who painted this."

\section{BIBLIOGRAPHY}

AlPers 1988 - Alpers, Svetlana: Rembrandt's Enterprise. The Studio and the Market, Chicago: The University of Chicago Press, 1988.

Apollinaire 1912/1960 - Apollinaire, Guillaume: Du sujet dans la peinture moderne (1912), in Chroniques d'art (1902-1918), Paris: 1960.

BÄtschmann 1982 - BÄtschmann, Oskar: Dialektik der Malerei von Nicolas Poussin, München: Prestel, 1982.

BAUCH 1966 - BAuch, Kurt: Rembrandt. Gemälde, Berlin: 1966.

Berger 2000 - Berger Jr., Harry: Fictions of the Pose. Rembrandt against the Italian Renaissance, Stanford CA.: Stanford University Press, 2000

Blankert 1973 - BlanKERT, Albert: Rembrandt, Zeuxis and Ideal Beauty, in Album Amicorum J. G. van Gelder, The Hague: Martinus Nijhoff, 1973, 32-39.
Boenm 1995 - Boenm, Gottfried: Die Wiederkehr der Bilder, in Was ist ein Bild? Hrsg. Boenm, G., München: Fink, 1995, 11-38.

BRÓDY 1924 - BRÓDY, Sándor: Rembrandt szemben önarcképével [Rembrandt in front of his self-portrait], in Rembrandt. Egy arckép fényben és aranyban [1924] [Rembrandt. A portrait in light and gold], Budapest: Szépirodalmi Kiadó, 1973, 140.

Broos 1970 - Broos, B. P. J.: The 'O' of Rembrandt, Simiolus, Netherlands Quarterly for the History of Art 4. 3. 1970. 150-185.

Chapman 1990 - Chapman, H. Perry: Rembrandt's Self-Portraits. A Study in Seventeenth-Century Identity, Princeton-New Jersey: Princeton University Press, 1990.

Chapman 2005 - Chapman, H. Perry: The Imagined Studios of Vermeer and Rembrandt, in Inventions of the Studio, 
Renaissance to Romanticism, ed. ColE, Michael, Chapel Hill: Mary Pardo, 2005.

Chenault-Porter 1988 - Chenault-Porter, Jeanne: Rembrandt and His Circles: More about the Late Self Portrait in Kenwood House, in The Age of Rembrandt. Studies in Seventeenth Century Dutch Painting, ed. by FLEISCHER, Roland E. - SCOTt Munshower, Susan, 1988. (Papers in Art History from the Pennsylvania State University, Vol. III)

Corpus IV 2005 - Stichting Foundation Rembrandt Research Project, A Corpus of Rembrandt Paintings. Vol. IV. Self Portraits, ed. van DE WeTERInG, Ernst et. al., Dordrecht: Springer, 2005.

De Beaufort 1957 - De Beaufort, Henriette L. T.: Rembrandt, Haarlem: Tjeenk Willink, 1957.

Dilthey 1900/1996 - Dilthey, Wilhelm: The Rise of Hermeneutics, in Selected Works, Volume IV: Hermeneutics and the Study of History, [1900], Princeton - New Jersey: Princeton University Press, 1996, 235-260.

EMMENS 1968 - EMMENS, Jan Ameling: Rembrandt en de regels van de kunst, Utrecht: Haentjens, Dekker \& Gumbert, 1968.

ERPEL 1969 - ERPEL, Fritz: Rembrandts Selbstbildnisse, Berlin: Henschel Verlag, 1969.

GADAmER 2004 - GADAMER, Hans-Georg: Truth and Method, trans. Glen-Doeper, W., Bloomsbury, 2004.

Genette 1972 - GenetTe, Gérard: Narrative Discourse: An Essay in Method, Ithaca: Cornell University Press, 1972.

GERSON 1961 - GerSON, Horst: Seven Letters by Rembrandt, transcribed by van EEGHEN, I. H., trans. by Ovink, Yda D. The Hague: K.J.C Boucher, 1961.

GERSON 1968 - Gerson, Horst: Rembrandt Paintings, New York: Harrison House Publishers, 1968.

GOMBRICH 1960 - GOMBrich, Ernst H.: Art and Illusion. A Study in the Psychology of Pictorial Representation, London: Phaidon, 1960.

Gombrich 1976 - Gombrich, Ernst H.: The Heritage of Apelles, in Gombrich, The Heritage of Apelles - Studies in the Art of the Renaissance, London: Phaidon, 1976.

Hoogstraten 1678 - Hoogstraten, Samuel van: Inleyding tot de hooge schoole der schilderkonst: anders de sichtbre werelt, Rotterdam, 1678 - http://www.dbnl.org/tekst/ hoog006inle01_01/

HoubraKen 1718-1721 - HoubraKen, Arnold: De Groote Schouwburgh der Nederlantsche konstschilders en Schilderessen, 3 delen, Amsterdam, 1718-1721.

Kat. London - The Hague 1999 - Rembrandt by Himself, eds. White, Christopher - Buvelot, Quentin, London: National Gallery, and The Hague: Royal Cabinet of Paintings, Mauritshuis, 1999.

KemP 1986 - KeMP, Wolfgang: Rembrandt: Die heilige Familie oder die Kunst, einen Vorhang zu lüften, Frankfurt am Main: Fischer, 1986.

Kemp 2001 - Kemp, Wolfgang: Teleologie der Malerei. Selbstporträt und Zukunftsreflexion bei Poussin und Velázquez, in Las Meninas im Spiegel der Deutungen. Eine Einführung in die Methoden der Kunstgeschichte. Hrsg. von GREUB, Thierry, Berlin: Reimer Verlag, 2001, 235-246.

Krauss 1985 - Krauss, Rosalind E.: Notes on the Index, I-II., in KRAUSS, The Originality of the Avant-Garde and Other Modernist Myths. Cambridge, Mass., London: MIT Press, 1985, 196-219.

KrIS-Kurz 1934/1979 - KrIS, Ernst - Kurz, Otto: Die Legende vom Künstler. Ein geschichtlicher Versuch, Wien,
1934. English trans.: The Legend, Myth and the Magic in the Image of the Artist. A historical experiment, New Haven and London: Yale University Press, 1979.

VAN MANDer 1604 - VAn Mander, Karel: Den Grondt der Edel Vry Schilder-Const, Haarlem, 1604, in Het schilder-boeck: Het Leven van de Doorluchtighe Nederlantsche en Hoogduytsche Schilders, 1604 (facsimile van de eerste uitgave, Utrecht: Davaco Publishers, 1969, see http://www.dbnl.org/tekst/mand001schi01_01/mand001schi01_01_0051.htm)

MANUTH 1999 - MANuth, Völker: Rembrandt and the Artist's Self Portrait: Tradition and Reception, in Rembrandt by Himself, Catalogue of the exhibition in the National Gallery, London, eds. Brown, Christopher \& Buvelot, Quentin, The Hague, 1999, 38-57.

Marin 1999 - Marin, Louis: Sublime Poussin, Stanford: Stanford University Press, 1999, 202.

Miedema 1971 - Miedema, Hessel: The O's of Broos, Simiolus, Netherlands Quarterly for the History of Art 5. 1971. 185-186.

Moffit 1984 - Moffitt, John F.: 'Piú tondo che l'O di Giotto'. Giotto, Vasari and Rembrandt's Kenwood House Self Portrait, Paragone 35. 407. 1984. 63-70.

Müller 1997 - Müller, Axel: Die ikonische Differenz. Das Kunstwerk als Augenblick, München: Fink, 1997.

Neumann 1922 - Neumann, Carl: Rembrandt, 2 Bde, München: Verlag von F. Bruckmann AG, 1922.

PINDER 1943 - PINDER, Wilhelm: Rembrandts Selbstbildnisse, Königstein im Taunus: Karl Robert Langewiesche Verlag, o.J. [1943].

Pliny 1952 - Pliny: Natural History, trans. RackHam, H. London: Loeb Classical Library, 1952.

RÉNYI 1999 - RÉNYI András: A tenyér ünnepe [The Feast of the palm], in RÉnYI, András: A testek világlása. Hermeneutikai tanulmányok ['Lichtung' of Bodies. Studies in Hermeneutics], Budapest: Kijárat, 1999.

RÉNYI 2007 - RÉNYI, András: A reveláció retorikája [The Rethoric of Revelation], Mũvészettörténeti Értesítô 56. 2007. 139-147.

Rosenberg 1948 - Rosenberg, Jakob: Rembrandt, Life and Work, Oxford: Phaidon, 1948.

Schama 1999 - Schama, Simon: Rembrandts Augen, Berlin: Siedler Verlag, 1999.

SCHWARTZ 1977 - SCHWARTZ, Gary: The Complete Etchings of Rembrandt. Reproduced in Original Size, New York: Dover Publication Inc., 1977.

SCHWARTz 1984/1991 - SCHWARTZ, Gary: Rembrandt. His Life, His Paintings (1st ed. New York: Penguin Books, 1985) 2nd. ed. London: Penguin, 1991, originally: SCHWARTZ, Gary, Rembrandt, zijn leven, zijn schilderejen: een nieuwe biografie met alle beschickbare schilderjen in kleur aufgebeld, Maarssen: SDU, 1984.

SCHWARTZ 1993 - SCHWARTZ, Gary: Rembrandt Research after the Age of Connoisseurship, in Annals of Scholarship. An International Quarterly in the Humanities and Social Sciences 10. 3-4. 1993. 313-335; available also on Internet at http://schwartzlist.com/2010/04/01/rembrandt-research-after-the-age-of-connoisseurship/

Simmel 1917/2005 - Simmel, Georg: Rembrandt. Ein kunstphilosophischer Versuch, Leipzig: Kurt Wolff Verlag, 1917; English translation: Rembrandt: An Essay in the Philosophy of Art, trans.: Scott, Alan - Staubmann, Helmut, New York: Routledge, 2005. 
SIX 1908 - SIX, Jan: Rembrandts voorbereiding van de etsen van Jan Six en Abraham Francen, Onze Kunst XIV. II. 1908. 53-65.

Stoichita 1998 - Stoichita, Victor I.: Das selbstbewußte Bild. Vom Ursprung der Metamalerei, München: Fink, 1998.

Stoichita 2001 - StoichitA, Victor I.: Imago Regis: Kunsttheorie und königliches Porträt, in Las Meninas im Spiegel der Deutungen. Eine Einführung in die Methoden der Kunstgeschichte. Hrsg. von GreuB, Thierry, Berlin: Reimer, 2001. 207-234.

STRAUSS - VAN DER MEULEN 1979 - The Rembrandt Documents, eds. Strauss, Walter L. - VAn Der Meulen, Marjon, with the assistance of DUDOK VAN HEEL S.A.C., and DE BAAR, P.J.M., New York: Abaris Books, 1979.

VAN DE WAAL 1956 - vAN DE WAAL, Henri: Rembrandt 1956, Museum: Tijdschrift voor filologie en geschiedenis LXI. 1956. 193-209.

VAN DE WAAL 1967 - VAN DE WAAL, Henri: The linea summae tenuitatis of Apelles: Pliny's Phrase and Its Interpreters,
Zeitschrift für Ästhetik und allgemeine Kunstwissenschaft XII. I. 1967. 5-32.

VAN DE Wetering 1997 - VAN DE Wetering, Ernst: Rembrandt. The Painter at Work, Amsterdam: Amsterdam University Press, 1997.

VAN DE Wetering 1999 - VAN DE Wetering, Ernst: The Multiple Functions of Rembrandt's Self Portraits, in Kat. London - The Hague 1999.

VAN DE Wetering 2005 - VAN DE Wetering, Ernst: Rembrandt's Self-Portraits: Problems of Authenticity and Function, in Corpus IV. 2005. 89-317.

van Gelder 1969 - Van Gelder, J. G.: Rembrandt en de zeventiende eeuw, De Gids 1969, 397-413.

VASARI 1551/1878-1885 - VASARI, Giorgio: Le vite de'più eccellenti pittori, scultori ed architettori, ed. Milanesi, Gaetano, Firenze: G. C. Sansoni, 1878-85, 9 Vols.

Waldenfels 2004 - WALdenfels, Bernhard: Phänomenologie der Aufmerksamkeit, Frankfurt a. M.: Suhrkamp, 2004.

WeisBach 1926 - WeisBaCH, Werner: Rembrandt, Berlin: Propylaen, 1926.

\section{NOTES}

${ }^{1}$ Rembrandt: Self-Portrait with Two Circles, 1665; oil on canvas, $114.3 \times 94 \mathrm{~cm}$; London, Kenwood House, The Iveagh Bequest, inv. no. 57. See Corpus IV 2005, IV 23.

${ }^{2}$ Rembrandt: Self-Portrait with Easel, 1660; oil on canvas, $110.9 \times 90.6 \mathrm{~cm}$; Paris, Louvre, inv. no. 1747 . Corpus IV 2005, IV 19; Br. 53.

${ }^{3}$ Rembrandt: Self-Portrait as Zeuxis, 1662-63; oil on canvas, $82.5 \times 65 \mathrm{~cm}$; Köln, Wallraf-Richartz Museum, inv.no. 2526. Corpus IV 2005, IV 25; Br. 61. On its iconography, cf. Blankert 1973

${ }^{4}$ The very early, stunning little genre painting, Artist in His Studio (1629, Boston, Br. 419), could hardly be considered a self-portrait in the emphatic sense.

5 CHAPMAN 1990, 98.

${ }^{6}$ BRÓDY 1924, 140.

${ }^{7}$ GADAMER 2004, 60-61.

8 Simmel 1917/2005, 27.

${ }^{9}$ To cite only the most important ones: Die ästhetische Bedeutung des Gesichtes (1901), in SimmEL, G.: Das Individuum und die Freiheit, Essais, Berlin, 1984, 140-145; Ästhetik des Porträts (1905), in Simmel: Vom Wesen der Moderne. Essays zur Philosophie und Ästhetik, hrsg. v. Jung, W., Hamburg, 1990. 277-293; Das Problem des Porträts (1918), in SimMEL: Zur Philosophie der Kunst, Philosophische und kunstphilosophische Aufsätze, hrsg. von SimmeL, Gert, Potsdam, 1922. 96-109.

10 SiMMEL 1917/2005, 18.

11 Simmel 1917/2005, 17.

12 SimMel 1917/2005, 98-100.

13 Simmel 1917/2005, 20.

${ }^{14}$ It is a well-known fact that Simmel's philosophy, which stems from the Romantic tradition, emerged as a cultural critical reflection on the increasingly materialistic social life of the turn of the century, as well as its intellectual underpinnings, positivism and historicism (and art historiography of a like persuasion): in this regard, the philosophy of the portrait, expounded in Rembrandt and based on the immediacy of the aesthetic consciousness, can be read as the ideal type of the extraordinary, redeeming function attributed to art, as a kind of aesthetic utopia. Note that in Simmel the absolutely autonomous work of art is "unrelated to reality," its truth is above even the alternatives of "appearance or reality."

${ }^{15}$ On the victory of "life that leaves behind form," cf. NEUMANN 1922, Vol. I, 32. On his part, Neumann sums up the psychology of the late portraits thus: "More and more, Rembrandt withdraws into himself: there is something distrustful in what his face expresses, something that is almost hostilely defensive and is not without bitterness: this should suggest what a fine, sensitive soul this man had... both admired in his life and knocked around, he was never broken. He amassed a devilish will power - though it was the will to resist, not to act -, and this is what informs the defensive expression that marks all his late paintings [...] He has reached a victorious height where his ever-growing knowledge will no longer lead him astray." In this context, Neumann represents the picture at Kenwood House as self-idealization in the form of a noble old man, as self-representation in the guise of a "sovereign." But this has none of "the euphoria of victory or the posturing of the victor. He looks at us bitterly, yet certain of his self-identity, confidently in possession of the rights he has won; a hunted, abandoned, dethroned king - yet still stately, still a king." Cf. Neumann 1922, Vol. II, 541-543.

${ }^{16}$ In his 1948 monograph, Jakob Rosenberg, for instance, places the emphasis on Rembrandt's search for objectivity, rather than his egocentrism. The visitor, he writes, of an imaginary exhibition of all of Rembrandt's self-portraits could not but "be impressed by the ceaseless and unsparing observation which the paintings reflect, showing a gradual change from outward description and characterization to the most penetrating self-analysis and self-contemplation. [...] Rembrandt seems to have felt that he had to know himself if he wished to penetrate the problem of man's inner life" Rosenberg 1948, 37. Fritz Erpel thinks Rembrandt's self-representations reveal first the rise of a talented, ambitious bourgeois, then the story of how a lonely creator who 
considers his world ever more critically is forced on the defensive, which eventually leads, in the late works, to the final meditations of an artist who "withdraws more and more from society, while getting closer and closer to humanity". Cf. ERPel 1969, 55.

17 Pinder 1943, 3. The topos already appears in Neumann, who thinks Rembrandt's series of portraits is comparable to the autobiographies of the greatest authors, such as St Augustine, Rousseau or Goethe. Cf. Neumann 1922, Vol. II, 538.

18 Cf. Dilthey 1900/1996.

19 PINDER 1943, 97-98.

${ }^{20}$ Pinder 1943, ibid.

${ }^{21}$ Nowhere in his lengthy work does Simmel examine how that "unfolding" takes place in a given picture, nowhere does he register original, unusual visual experiences, and where he does ask "what can we see in the picture," he provides general answers. Simmel 1917/2005, 138-145.

22 Simmel himself disputes in his foreword whether scholarly scrutiny can ever get close to the totalizing experience of unity that the aesthetic experience offers. Cf. SimMEL 1917/2005, 5-7.

${ }^{23}$ For a comprehensive overview of the problem, cf. VAN DE Wetering 1999, $17 \mathrm{ff}$. Cf. also the introduction of Corpus IV 2005, XXIIIff.

${ }^{24}$ For a detailed summary, cf. ChEnAUlT-PorTer 1988, 189. For the current state of research, cf. Corpus IV 2005 , XXXIV, IV-26, 565-568.

25 Weisbach 1926, 536.

26 "... de twee half-ronden van een als wandversiering dienende wereldkaaart": VAN DE WAAL 1956, 199.

27 Jan Miense Molenaer: The Painter in His Studio, cca. 1631; oil on canvas, $86 \times 127$ cm; Berlin, Gemäldegalerie.

${ }^{28}$ BAUCH 1966, 17, n. 331.

${ }^{29}$ CHAPMAN 1990, $99 \mathrm{ff}$.

30 The map of the spheres on the wall of Rembrandt's studio would then indicate the kind of universality that Samuel van Hoogstraten demanded of all painters of significance in the foreword of his Inleyding tot de Hooge Schoole der Schilderkonst (cf. Hoogstraten 1678). In the etching of the title page, Clio, the muse of fate, is among those who show the painters-to-be the way to the future: the "universe" is symbolized by the globe in the lower right corner, bisected by the edge of the picture. Chapman suggests there is a good reason for the subtitle of the tome, De Zichtbaere Werelt, or, The Visible World: Hoogstraten considers the visibility of the world a challenge which only the painter can tackle; a heroic achievement that compares to that of the philosopher, who reveals the laws of the invisible world. Cf. CHAPMAN 1990, 99.

31 De BeAufort 1957, 112-113.

32 VAN GELDER 1949, 408-409. It also detracts from the persuasive power of his assumption that the circles whose movement Aristotle discusses in Mechanica are concentric. Cf. Moffit 1984, 63, and 67, n. 2.

33 Emmens 1968, 174-175. Both Broos and Moffit point out that Emmens' speculation is wrong because Ripa's figures concern measuring, not drawing.

34 MofFit 1984, 63-70.

35 BROOS 1970.

36 VASARI 1551/1878-1885, Vol. I, 383

37 VAN MANDER 1604, Vol. III, fol. 96b.
${ }^{38}$ Which he then eliminated in the fifth version. Cf. Rembrandt: Lieven Willemsz. Van Coppenol. B. 282. Cf. SCHWARTZ 1977, B. 282.

${ }^{39}$ At the end of his story van Mander quotes the saying on somebody's fatness "You are much rounder then the $\mathrm{O}$ of Giotto" from Vasari. See Broos 1970, 175, n. 40.

40 Broos 1970, 182.

${ }^{41}$ Several details of the painting, especially the hand with the palette, must have filled classicistic art lovers with horror, because they are far from being "finely" executed. Houbraken's criticism of Rembrandt's technique, which he committed to paper in 1719 , reflects the opinion of the painter's contemporaries, handed down as oral tradition: "One regrettable circumstance is that he was so quick to make changes, or compelled to try something new, that he only half-finished many of his things, paintings as well as prints. The ones that are finished give us an idea of what a magnificent [oeuvre] we should have had from his hand had he finished everything in the same measure [of excellence] as he began ... It went the same way with his paintings. I have seen some with [passages where] the objects were brought to a high degree of finish while the rest was smeared on without regard for drawing, as if it were done with a coarse tar-brush. Nor was he to be budged on this point. His answer was that a piece was finished when the master had achieved his intention in it." HoUbRAKEN 1718-1721, Vol. I. 259. The complete text of the second edition of 1753 can be found at http://www.dbnl.org/tekst/houb005groo01_01/index.htm. The English translation is from Broos 1970, 182.

42 VAN DE WETERING 1997, 87.

${ }^{43}$ Puiny, Naturalis Historia, XXXV. 81-83. Kris and Kurz summarize the story thus: "In Pliny's version, Apelles visits Protogenes' house on Rhodes and, in his host's absence, draws an exquisitely fine line on a panel. Without making his presence known in any other way, he leaves it behind as a kind of visiting card. Protogenes recognizes the hand of Apelles, paints a second, even thinner line over that of Apelles, and hides when Apelles repeats his visit in the hope that he will witness Protogenes' discomfiture. Apelles, however, succeeds in painting a third line on top of the second one. Duris, who is credited with the invention of this tale ... here pins the theme of the artists' rivalry ... to the artist's most abstract accomplishment. In later times, repeated attempts were made to give this story different and more lively reinterpretations. Entirely in keeping with what the early Quattrocento deemed to be the most important artistic task, Lorenzo Ghiberti [...] proposed that one had to assume that it was problems of perspective in which Apelles and Protogenes were trying to outdo one another. Such reinterpretations, however, deprive the anecdote of its exemplary content - which is nothing other than sheer virtuosity. A modern variation of the same theme is the story of Giotto who, to prove his mastery, drew a perfect circle freehand in the presence of an astonished papal emissary." KRIS-KuRZ 1934/1979, 96-97.

${ }^{44}$ Miedema 1971, 185-186.

45 VAN DE WAAL 1967; PLINY 1952.

${ }^{46}$ VAn DE WAal quotes PlinY: Naturalis historia XXXV, 81. The English translation is Pliny 1952, IX, 323.

${ }^{47}$ Let meg quote van Mander: "But to give my opinion freely, I do not believe that these were simple straight lines or strokes, as many think who are not painters, but rather 
a contour of an arm or a leg, or a profile of a face or something similar, which were very delicately set down in various colours and intersecting with each other in various places, which Pliny meant to indicate by cleaving (secuit). For the scholars who are not well acquainted with our art write and speak about it uncomprehendingly. And I strengthen my case with the fact that Pliny asserts that those who had an understanding of painting were very much astonished and amazed by it. From this one can conclude that it was skilful contours and not simple lines that these two most excellent masters of our art had drawn in competition with each other; for many a schoolmaster can draw a straight line freehand while writing, or someone else who is no painter often can do better than the best painter in the world; and such a thing is considered no high achievement among painters, since they can use a ruler for it. But the knowledgeable in art are astonished and delighted when they see a characteristic and skilful contour, cleverly set down with the greatest knowledge, wherein the art of drawing consists in the fullest measure; but they would walk by straight lines without paying attention." VAN MANDER 1604, fol 78r. The English translation is from VAN DE WAAL 1967, 6.

48 Apollinaire 1912/1960.

${ }^{49}$ VAN DE WAAL $1967,12$.

50 GOMBRICH 1976, 15-18.

${ }^{51}$ In a footnote of his cited study (Broos 1970, 181, n. 48) Broos refers to an article from the early twentieth century, in which Jan Six suggests, only to dismiss the idea, that the two circles in the picture at Kenwood House may have something to do with the legend recorded by Pliny. Cf. Six 1908, 65

52 SCHWARTZ 1984/1991, 352.

53 In English: An Expression of Gratitude to the Excellent and Widely Renowned Rembrandt van Rijn, in STRAUSS - VAN DER MEulen 1979, 172-173. Cf. also: EMmens 1968, 205, and CHENAULT-PORTER 1988.

${ }^{54}$ Nor does Gombrich leave the motif unmentioned, though he cites Pliny as the source. Cf. Gombrich 1976.

55 "...om ene enkele parel kracht te doen hebben, een schone Cleopatra zou hebben overtaant". HoubRAKEN 1718-1721, Vol. I, 259. For a careful interpretation of the passage, cf. VAN DE WETERING 1997, 167-168.

56 SCHWARTZ 1984/1991, 354.

${ }^{57}$ I cannot discuss here the modernist and formalist readings of the painting at Kenwood House, but it is certainly true that its unusual composition does encourage some to draw bold conclusions. Even the influential Rembrandt expert and great connoisseur Horst Gerson was sceptical about attaching an allegorical or symbolic explanation to the circles. In his 1968 oeuvre catalogue, a revision of Bredius's 1935 catalogue of the paintings, he lent his support to the position that the motifs in question merely serve to emphasize the geometric structure of the picture, "void [as they are] of all informational or decorative content, presenting themselves as pure geometric forms. This kind of abstractionism is also expressed in the palette, brushes, and maulstick, though these remain legible as objects." Cf. GERSON 1968, 142. Cf. also cat. no. [380], 503. Gerson too cites the editorial of The Burlington Magazine on the 1950 reopening of the Iveagh Bequest at Kenwood House, in which the editor regretted that the late Roger Fry, the legendary proponent of the moderns, did not live to see the splendid Rembrandt in its cleaned state, "since of all the self-portraits, the Kenwood picture is structurally the most rigid and, therefore, the one on which he could have been most enlightening. It seems as though Rembrandt, soaring across two centuries, had wished to experiment with straight lines and curves, to try out on a private canvas for possible public use certain devices that tend towards geometry. No other explanation will fit the circles on the wall behind him, the angular, 'unrealistic' contours of the right sleeve, the diagrammatic palette, the continuation of the line of the mahlstick into the background, or the studied placing of the head a little to the left to allow for the inclusion of the sharp triangle of canvas in the top right-hand corner. ([Footnote:] The canvas had been painted out, and was only revealed on cleaning. The picture had been heavily varnished in the frame, as is proved by a strip under the frame which showed the original tone and colour of the background.) The name of Cézanne must inevitably spring to the mind of even the most austere historian when faced with this fur collar, rendered in superimposed, rectangular, flat areas of paint, or with the right sleeve, indicated by a series of overlapping, quilt-like patches, almost unknown to art before 1885. Yet the portrait is much more than 'modern,' more than a startling essay in composition: its geometry is only the solid framework in which fierce sensations are left to glow." The Burlington Magazine, Editorial, No. 568. Vol. XCII, July 1950.

58 If, as Blankert instructs us (cf. BlanKerT 1973), we consider the Laughing Self-Portrait of Cologne (Fig. 3) from the perspective of the 1685 Self-Portrait with Zeuxis (Frankfurt am Main, Städel), by Aert de Gelder, a student of Rembrandt, it becomes evident that the silhouette of a face in the upper left corner in fact appears on a canvas facing the viewer.

${ }^{59}$ Cf. Kat. London - The Hague 1999, cat. No. 83, 220.

${ }^{60}$ Cf. Corpus IV 2005, IV 26, 564-565.

${ }^{61}$ Chapman 2005, 126.

62 Though it is not uncommon for the head and the torso to make a contrast-rich appearance before the background like a silhouette (e.g. Br.59, Rijksmuseum), nowhere else can we see a support of this kind, which runs through the entire width of the picture field, and is barely differentiated and highly planar in effect.

${ }^{63}$ Cf. my study on the Copenhagen Emmaus: RÉNYI 2007

${ }^{64} \mathrm{Cf}$. Wolfgang Kemp's monograph on the Kassel Holy Family: KeMP 1986.

${ }^{65}$ Cf. Stoichita 1998, 235-257.

66 Kemp 2001, 240.

${ }^{67}$ Pascal, Blaise: Pensées, Section 10, par. 678.

68 BäTsCHMANn 1982, 60

${ }^{69}$ Marin thinks the main reason we cannot see the picture with the allegory of Painting is not the grey canvas but the fact that it "is hidden by the painting at which we are looking along with Poussin and Chantelou." The subject of the picture is painting, which becomes visible in this very "in between," this rift, as does the subject of the painting, the painter himself. Cf. MARIN 1999, 202.

${ }^{70}$ Poussin's letter to Chantelou, 19 June, 1650; quoted in Kemp 2001, 240.

${ }^{71}$ Kemp 2001, 240.

72 Which, as we know, did come about eventually, unlike in the case of Poussin. Cf. Corpus IV 2005, 28, 311; Cf. also MANUTH 1999, 48ff. 
${ }^{73}$ In his letters to Constantijn Huygens, Rembrandt frequently declares he hopes his paintings will receive adequate illumination: when on 27 January, 1639, he sends a picture as a gift to the secretary (probably The Blinding of Samson, now at the Städel, Frankfurt), he makes a point of warning him about the proper way of hanging it, "so it will sparkle at its best." On Rembrandt's correspondance with Huygens, cf. GERSON 1961. Also of interest here is an anecdote handed down by Houbraken about Rembrandt shooing away a visitor who tried to look at a painting too closely, warning that "the smell of the oil paint will make you sick." HOUBRAKEN 1718-1721, Vol. 1, 269.

${ }^{74}$ As regards its size, the painting hidden from the viewer, on which he is working, corresponds to the real canvas at the Prado: the play with the identity of the real and the painted painting, with the mirror and the models, as well as Velázquez's unparalleled representational power, together create a paradoxical illusion of reality, which is probably best summed up by Théophile Gautier's famous exclamation: "Mais où est donc le tableau?" As we shall see, Rembrandt also made use of the effect in the Kenwood portrait.

75 KeMP 2001, 242.

${ }^{76}$ C. GenetTE 1972.

77 BOEHM 1995, 29-36; MÜLler 1997.

${ }^{78} \mathrm{His}$ argument is that art involves the viewer similarly to how a player enters a game: the work of art offers certain shared (culturally inherited) rules, and requires her to know and accept them, as well as to subordinate her subjective goals to the occurrence of the shared event she is ready to take part in. As a good player will want to win (will enjoy the game) only through adherence to the mutually accepted rules, so a good recipient will not yield to a whim, to the assertiveness of her subjectivity, when experiencing and assessing a work of art. She knows it is not the occasional object of experience she can simply invade and "use" at will, and consequently agrees to follow its "rules" when entering its domain. The form of the work of art may be nothing but a system of instructions, directions and allusions for the observer, which the good viewer (one who is competent, and knows and understands the rules) can and is willing to pay attention to, seek out and follow. She does so while knowing that delights, torments and insights await her in the course of this active observation - she is ready to expose herself to unknown experiences.

${ }^{79}$ WALDENFELS 2004, $220 f$.

80 Though he is known to have painted a large number of self-portraits, Rembrandt seldom used objective-spatial indicators (banisters, room interiors, cast shadows, etc.) to position the figure in space: even the early works are marked by a concentration on the face and the expression, which necessarily entails the semantic voiding of the visual environment. Figuratively speaking, the background is pushed more and more into the background, usually becoming a mere negativity, a contrasting foil without which the figure could not emerge, of course, but which is reduced to virtual invisibility. Even in his self-portraits, Rembrandt often creates the illusory power of personal presence by suppressing the elementary dialectic of the picture, the dialogue of figure and ground.

81 See Gombrich 1960, 181-287; Houbraken 1718-1721, Vol. I. 259.

${ }^{82}$ Cf. van de Wetering 2005, 305.
${ }^{83}$ Corpus IV 2005, 308.

${ }^{84}$ The painting in question is Woman with Carnation (Br. 398) at the Statens Museum for Kunst, Copenhagen, dated to 1656, in which the surface of the face is marked by what is doubtlessly an extremely fine brushwork. E. van de Wetering also highlights the broader art historical context of the representation of human skin. In addition to Lampsonius, he also quotes Vasari's biography of Leonardo, the passage on Mona Lisa ("The eyebrows, through his [Leonardo's] having shown the manner in which the hairs spring from the flesh, here more close and here more scanty, and curve according to the pores of the skin, could not be more natural"), as well as Hoogstraten's remark on the same painting: "One sensed the little sweat holes in the tender skin." Cf. Hoogstraten 1678, 239. Quoted in VAN DE WETERING 2005, 309.

${ }^{85}$ Van de Wetering does not make the connection even though he quotes an expert of the physiology of vision, according to whom "in attempting to focus the optical image properly, the eye will hunt for critical details in the visual scene, a similar process that occurs when one tries to get a slide focussed on a projection screen. Last, but not least, there is also the aspect of mental focus, the mind's eye, which is attracted by details contrasting with the more roughly painted surround. All these effects work in the direction of locking the viewer's eye on to the face in the portrait, and making this face manifest itself in an inescapable manner" (VAN DE WeTERING 2005, 307, n. 415).

${ }^{86}$ GOMBRICH 1960, 184f. Also of interest here is Rembrandt's alleged remark, cited by Houbraken in the passage already quoted: "[H]e worked quickly, particularly in his last period, when his work, seen from nearby, would look as if it was smeared on with a trowel. Which is why, when people came to his studio and wanted to see his work at close range, he would pull them back saying 'the smell of paint will bother you"' Houbraken 1718-1721, Vol. I. 259. See also my former discussion of The Return of the Prodigal Son, in which I propose a possible aesthetic strategy for the suspension of acute vision. Cf. RÉNYI 1999, particularly 82-101.

${ }^{87}$ This was how he avoided looking left-handed. See the X-ray image in Corpus IV 2005 26, Fig. 2, 563. It is analyzed on page 565 .

88 Cf. e.g. SCHAMA 1999, 670.

${ }^{89}$ AlPERS 1988.

${ }^{90}$ Houbraken could just as well describe this work: "Among a multitude of his portraits that were worthy of fame there was one ... that he had painted after his own likeness which was so artfully and powerfully elaborated that even the most vigorous brushwork of Van Dyck and Rubens could not match it, aye, the head appeared to protrude from it and address the beholders." Houbraken, De Groote Schowburg, ed. cited, 12. The English translation is from Corpus IV 2005, 275.

${ }^{91}$ Berger 2000, $497 \mathrm{ff}$.

${ }^{92}$ Cf. note 50 .

93 Pliny, Hist. Nat. XXXV. 88.

${ }^{94}$ Translation from Broos 1970, 170.

95 KrIs-Kurz 1934/1979, 96.

${ }^{96}$ Launched in 1969, the scientistic Rembrandt Research Project (RRP) is based on the positivist notion that "authorship is the sum of physical conditions." For a critical view of the programme, cf. SCHWARTZ 1993. 
${ }^{97}$ KRAUSS 1985

${ }^{98}$ Pliny, Hist. Nat., XXXV. 83, cf. PuinY 1952, 184-185.

99 This could be the link surmised by C. H. A. Broos, between Rembrandt's "unfinished" style and the circles as symbols of perfection. The performative reading I propose may even obviate the rather fruitless debate about the question of completedness. Whoever ascribes the "sketchiness" of the lower part of the painting to mere incompletedness (implicitly expecting, that is, a future state in which things have reached their "final," finished form), practically falls for the trick of the painting, and cannot help seeing it as the complete representation of fixed identities. Cf. BROOS 1970, 182-183, n. 51

100 There is no room here to elaborate on how Rembrandt provides different emphases and directions of content for the performative games that these paintings - the one at Kassel more playful, the other at Copenhagen disconsolately mournful - play with their viewers.

101 The material inspection of the painting at Kenwood House has suggested that the canvas was trimmed (cf. Corpus IV $2005,26,564)$, but by no more than a few centimetres on the right. The "canvas on the canvas" effect was thus probably more readily recognizable, but the suggestion that they were identical was still far more extraordinary than what was common at the time.

102 Cf. Stoichita 2001, 211.

${ }^{103}$ Magritte's famous La condition humaine (1933) (Fig. 12) could be considered a verification of this "non-classical," Rembrandtean teleology of painting; it too makes use of the metaleptic embedding of a picture within the picture, and the elusiveness of the inner frame (Cf. MülLER 1997). The relationship of the two works is of course not a case of the former influencing the latter: Magritte was not in any way directly interested in Rembrandt or the masterpiece at Kenwood House. Nevertheless, both are parts of the same
universal-European discourse about the nature of the easel painting and of autonomous (modern) painting. After all, Magritte thematizes an essential metaphor of this discourse, Alberti's finestra aperta - by making the painting that is placed in the window coincide with the garden which it represents and which the window overlooks. The picture practically posits a logical paradox, the quintessential identity of "reality" and "likeness" - also the highest utopia of painting in Alberti -, and presents it as the optical continuity of the real painting and the one included, interrupted only by a thin edge. The "real" painting representing the room and the "fictitious" painting in the plane of the window share a line of sight, though their picture planes do not coincide. Magritte escalates the subversive power of the iconic difference that is already manifest in Rembrandt, and heightens it to an open paradox. Given the above, note that while Magritte employs the motifs, theorems and language of painting, his work already has little to do with painting It is more of a painted, meta-painterly philosopheme than a painterly work: in no way does its understanding require the eye to perform the activity that reveals and realizes the iconic differences of paintings. Its language, which is decidedly neutral from a painterly perspective, the even illumination, the unproblematic, harmonized arrangement of surfaces, contours and colours, all serve a single purpose: to create the evident texture of the pure presentness and logical continuity of the objective world which his intellectual gag can tear up impressively. As it happens, the provocative absurdity of his act is rooted in the openness and immediacy of positing the deeply ambivalent as undeniably unambiguous. Magritte's painting implies a perfectly impersonal and motionless gaze, not merely not requiring, but expressly preventing, the viewer from bringing it in motion by her presence. It is a picture in which, once the joke has been understood, there is nothing left to see. 